\title{
Cisplatin effects on F-actin and matrix proteins precede renal tubular cell detachment and apoptosis in vitro
}

\author{
Maricke Kruidering ${ }^{1}$, Bob van de Water ${ }^{2}$, Yi Zhan², \\ Johan J. Baelde ${ }^{3}$, Emile de Heer ${ }^{3}$, Gerard J. Mulder ${ }^{1}$, \\ Jim L. Stevens ${ }^{2}$ and J.Fred Nagelkerke ${ }^{1,4}$ \\ ${ }^{1}$ Division of Toxicology, Leiden/Amsterdam Center for Drug Research, Leiden \\ University, P.0. Box 9503, 2300 RA Leiden, The Netherlands \\ 2 WA Jones Cell Science Center. 10 Old Barn Road. PO Box 49, Lake Placid, New \\ York 12946 USA \\ ${ }^{3}$ Department of Pathology, Leiden University, P.O. Box 9603, 2300 RC Leiden, \\ The Netherlands \\ ${ }^{4}$ corresponding author: Division of Toxicology, Leiden/Amsterdam Center for \\ Drug Research, Leiden University, P.0. Box 9503, 2300 RA Leiden, The \\ Netherlands. tel: 31-71-5276226; fax: 31-71-5276292; \\ e-mail: nagelker@lacdr.leidenuniv.nl
}

Received 29.9.97; revised 18.2.98; accepted 11.3.98 Edited by R.A. Knight

\begin{abstract}
In primary cultures of porcine proximal tubular kidney cells and LLC-PK1 cells cisplatin $(5-50 \mu \mathrm{M})$ caused apoptosis and cell detachment; in both systems cell detachment occurred, preceded by a loss of cytoskeletal F-actin stress fibers within 4-6 $h$, and a reduction of mRNA encoding for fibronectin, collagen $a_{2}$ type (IV) and laminin B2 within 17-41 h. Prevention of F-actin damage by phalloidin prevented nuclear fragmentation, suggesting a relation between F-actin damage and apoptosis. Overexpression of $\mathrm{Bcl}-2$ also prevented apoptosis, but did not prevent damage to the F-actin skeleton or the reduction of mRNA expression of the matrix proteins. These results suggest that $\mathrm{Bcl}-2$ overexpression interferes with apoptotic signals downstream of F-actin. The relevance of these results for cell detachment in kidney toxicity is discussed.
\end{abstract}

Keywords: extracellular matrix (ECM); cisplatin; nephrotoxicity; kidney; porcine; in vitro; bcl-2

Abbreviations: AcOr: acridine orange; ARF: acute renal failure; cispt: cisplatin; COL: collagen; EA: early apoptotic; ECM: extracellular matrix; EtBr: ethidium bromide; FN: fibronectin; GAPDH: glyceraldehyde-3-phosphate dehydrogenase; GGT: gamma-glutamyl transpeptidase; HH-buffer: Hanks'-HEPES-buffer; LA: late apoptotic; LN: laminin; NEO: neomycin; PI: propidium iodide; PPTC: porcine proximal tubular cells; VIFM: videointensified fluorescence microscopy

\section{Introduction}

Cisplatin, one of the most effective chemotherapeutic agents currently available, is used in the treatment of a wide range of neoplasms (Prestayko et al, 1980). The major side-effects of cisplatin-treatment are acute and chronic nephrotoxicity. Acute toxicity, characterized by necrosis in the $S_{3}$ segment of the proximal tubule, has been studied extensively in laboratory animals. In humans, the pattern of cisplatin nephrotoxicity is similar, starting with acute proximal tubular dysfunction (Daugaard, 1990) The long-term effects of cisplatin on renal function are less well understood, especially the events leading to acute renal failure (ARF). Interestingly, exfoliated but still viable proximal tubular cells are observed in urine of cisplatin-treated patients suffering from ARF (Lam and Adelstein, 1986).

Although chemical-induced ARF is called 'acute tubular necrosis', little necrosis is observed in $S_{1}$ and $S_{2}$ segments of the tubules. Instead, gaps are found in the epithelium along the tubular basement membrane at sites where cells have exfoliated, together with regenerative changes in the adjacent tubular cells (Solez, 1991). Detachment of proximal tubular cells may contribute to the pathophysiology of ARF in three ways. First, loss of cells may lead to altered transport properties and abnormal tubular reabsorption. Secondly, detached tubular cells can cause tubular obstruction. Finally, at sites with a denuded basement membrane, the ultrafiltrate can leak back from the tubular lumen into the circulation (Andreucci, 1984).

Proximal tubular cells are attached to the basement membrane in vivo (and to the growth support in vitro) by means of the integrin family of cell surface receptors, consisting of two subunits $(\alpha$ and $\beta$ ) with domains on both sides of the cell membrane. The cytoplasmic domain interacts with the F-actin fibres of the cytoskeleton through talin, vinculin and $\alpha$-actinin, while the extracellular domain interacts with the extraceilular matrix (ECM), thus mediating cell adhesion (Zhang et al, 1995). Consequently, damage to F-actin or changes in ECM integrity can cause detachment of the cells. Changes in the expression level of integrins do not necessarily lead to epithelial cell detachment (Gallit et al, 1993).

In this study we investigated whether changes in F-actin and/or ECM production are involved in cell detachment induced by cisplatin. A reduction of cell-ECM contacts can cause apoptosis also known as 'anoikis' (Frisch et al, 1996), since the intact ECM-integrin contact sends a continuous anti-apoptotic signal to the cell (Ruoslahti, 1996). Also, an association between loss of a functional cytoskeleton and apoptosis has been shown recently (Brown et al, 1997; Van de Water et al, 1996); therefore, we investigated the relation between cisplatin-induced Factin damage and apoptosis.

To investigate the effects of cisplatin on F-actin, ECM component expression, cell detachment and apoptosis we used cultured porcine proximal tubular cells (PPTC), a model for human PTC that we characterized previously 
(Kruidering et al, 1994; 1997), and the porcine renal proximal tubular cell line LLC-PK1, The data show that reduced production of ECM components and F-actin damage was associated with cell detachment of viable, necrotic and apoptotic cells. Prevention of F-actin damage prevented apoptosis. Apoptosis could also be prevented by overexpression of the anti-apoptotic oncogene $b c /-2$, but this did not block F-actin rearrangement nor the decrease of production of ECM components, implying that $\mathrm{Bcl}-2$ affected apoptotic messengers downstream of $\mathrm{F}$-actin signalling.

\section{Results}

\section{Effects of cisplatin on cell adhesion and viability}

Exposure of a monolayer of PPTC to $10-50 \mu \mathrm{M}$ cisplatin for $17 \mathrm{~h}$ induced morphological alterations of the cells: they were rounded, smaller and appeared darker when analyzed by phase contrast microscopy. The number of cells with morphological alterations increased with cisplatin concentration. The monolayers exposed to 25 and $50 \mu \mathrm{M}$ cisplatin displayed some cell swelling, suggesting necrotic cell death. At this time point $(17 \mathrm{~h})$ no significant cell detachment had taken place. Exposure for $41 \mathrm{~h}$ induced a concentrationdependent disruption of the monolayer; the cells detached individually (Figure 1a-d, Table 1). Empty areas with complete detachment of cells could be observed, while other cells remained attached to the dish, suggesting loss of cellcell contact. Part of the cells had shrunk and were fully rounded but still attached to morphologically normal, adherent cells.

In the adherent cells, cisplatin induced a concentrationdependent decrease of viability: at $50 \mu \mathrm{M}$ cisplatin viability was decreased by almost $50 \%$ after $41 \mathrm{~h}$ (Table 1). Most, but not all of the detached cells were non-viable as determined by $\mathrm{PI}$ staining and flowcytometric analysis (Table 1). a
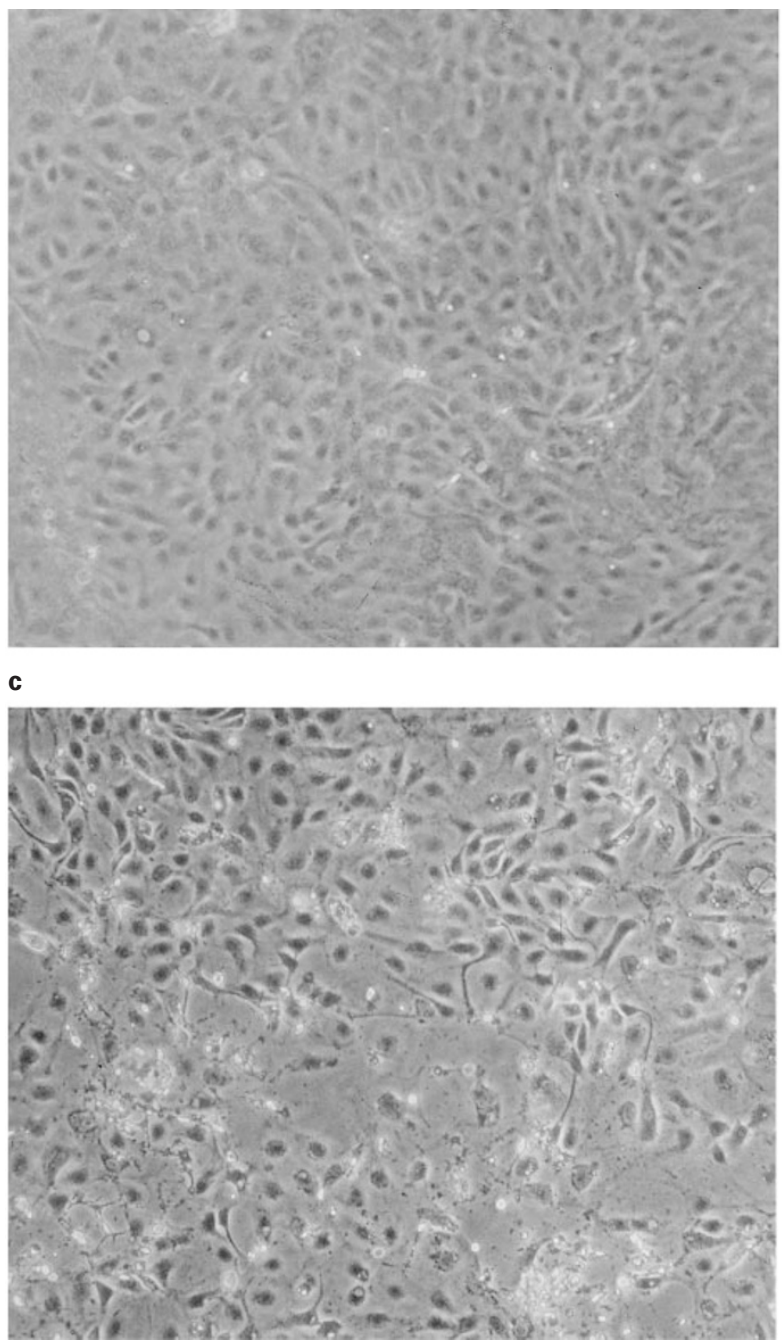

b

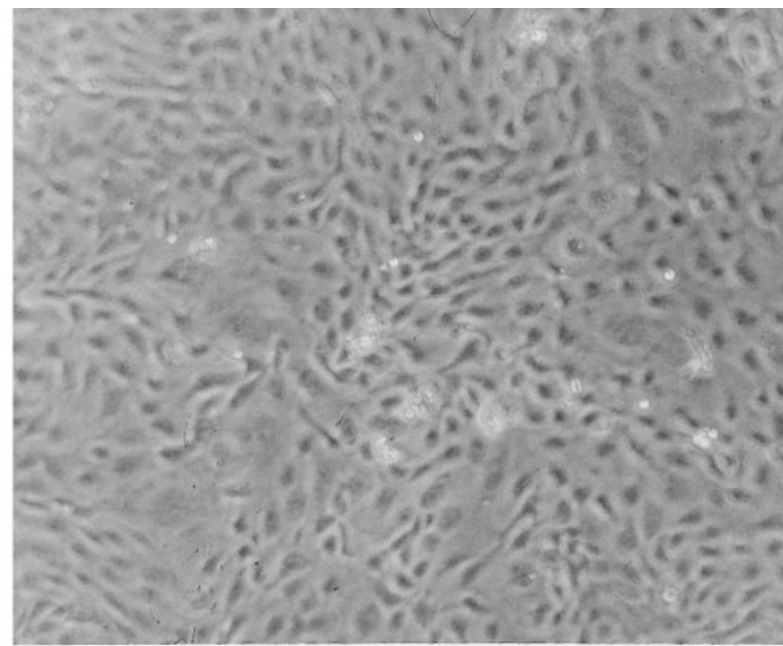

d

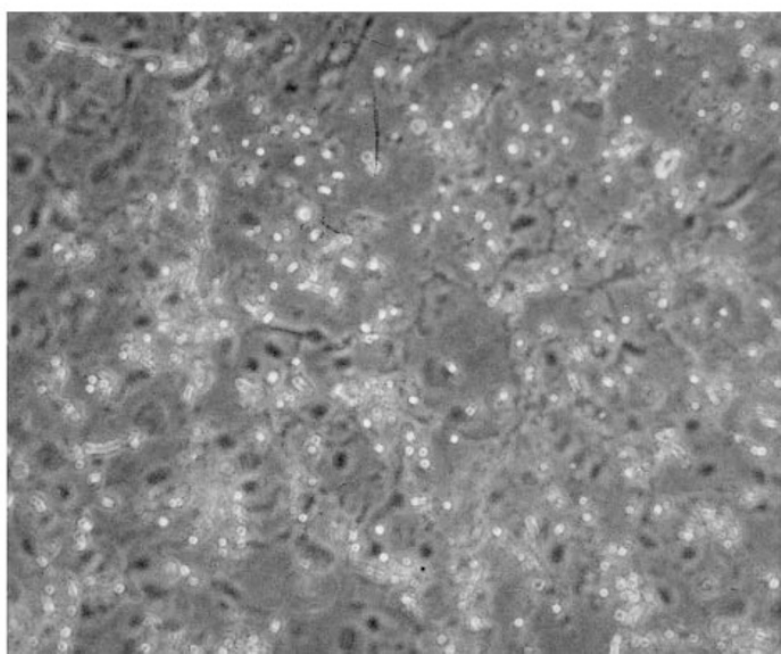

Figure 1 Phase contrast photomicrographs of PPTC exposed to cisplatin for $41 \mathrm{~h}$. Unexposed PPTC (A) display the cobblestone morphology of normal epithelial cells and exclude PI and trypan blue. Shown are PPTC exposed to $\mathrm{O} \mu \mathrm{M}(\mathbf{A}), 10 \mu \mathrm{m}(\mathbf{B}), 25 \mu \mathrm{M}(\mathbf{C})$ and $50 \mu \mathrm{M}$ cisplatin (D) for $41 \mathrm{~h}$. Note the empty areas in monolayers exposed to 25 and $50 \mu \mathrm{M}$ cisplatin (C and D) 
Exposure of the monolayers to $250-500 \mu \mathrm{M}$ cisplatin induced rapid cell swelling and death (necrosis) within $17 \mathrm{~h}$ (not shown).

\section{Cisplatin-induced cell death of PPTC: apoptosis and necrosis}

Cisplatin has been shown to induce both necrosis and apoptosis in mouse PTC in vitro (Lieberthal et al, 1996). We investigated the type of cell death using ethidium bromide (EtBr) and acridine orange (AcOr), allowing identification of viable, apoptotic and necrotic cells, based on colour and appearance. Viable cells take up AcOr, giving them a green colour. Non-viable cells take up EtBr, giving thern an orange colour. Both dyes intercalate into DNA allowing separation of four populations: (I) viable cells: green cells with intact nucleus; (II) early apoptotic cells: green cells with a fragmented nucleus; (III) late apoptotic cells: orange cells with a fragmented nucleus, and (IV) necrotic cells: orange cells with normal appearing nuclear structure (Lieberthal et al, 1996).

Whereas high concentrations $(500 \mu \mathrm{M}$ cisplatin $)$ induced rapid cell death by necrosis, $50 \mu \mathrm{M}$ and lower concentrations induced morphological changes in the nucleus characterized by condensed or a fragmented nucleus, associated with apoptosis (Figure 2). Cells exposed to $5-50 \mu \mathrm{M}$ cisplatin displayed both early (green) and late (orange) apoptotic morphology after staining with AcOr and $\mathrm{EtBr}$ (Figure 3). The percentage of apoptotic cells is shown in Table 2. In monolayers exposed to 5 and $10 \mu \mathrm{M}$ cisplatin only $4-9 \%$ of the cells were necrotic. At higher concentrations, i.e. $50 \mu \mathrm{M}$ and $500 \mu \mathrm{M}$, the percentage of necrosis increased to $25 \pm 14 \%$ (Table 2) and $87 \pm 3 \%$ respectively. The percentage of apoptotic cells of the detached cell population was also assessed. Approximately $40 \%$ of the detached cells of unexposed monolayers was apoptotic; this percentage was similar to that of detached cells from monolayers exposed to $5-50 \mu \mathrm{M}$ cisplatin (Table 3), although at increasing cisplatin concentration an increasing percentage of the cells detached (Table 1). At cisplatin concentrations above $50 \mu \mathrm{M}$ the detached cells were predominantly necrotic.

Table 1 Effect of cisplatin on viability and adherence of PPTC in culture

\begin{tabular}{lccc}
\hline & Detached cells & \multicolumn{2}{c}{ Viability } \\
Cispt $(\mu \mathbf{M})$ & \% of total & Detached \% & Attached \% \\
\hline 0 & $4 \pm 1$ & $37 \pm 1$ & $89 \pm 2$ \\
5 & $7 \pm 3$ & $14 \pm 2^{*}$ & $83 \pm 4$ \\
10 & $14 \pm 5^{*}$ & $9 \pm 1^{*}$ & $78 \pm 8^{*}$ \\
25 & $23 \pm 6^{*}$ & $10 \pm 2^{*}$ & $65 \pm 10^{*}$ \\
50 & $48 \pm 8^{*}$ & $8 \pm 1^{*}$ & $47 \pm 8^{*}$ \\
\hline
\end{tabular}

After $41 \mathrm{~h}$ of exposure, cells were rinsed with PBS, the floating cells were pooled and the remaining cells were harvested by trypsinization. Cells were counted and analyzed for PI exclusion by flow cytometry. Viability represents the percentage of PI negative cells. Values are mean \pm S.E.M. $(n=6)$; *significantly different from control $(P \leqslant 0.05)$

\section{Effects of cisplatin on the cytoskeleton: F-actin and microtubules}

Renal epithelial cells possess F-actin fibres located at the basolateral side of the cells, known as stress fibres, and an apical pool of actin involved in formation of adherent junctions.

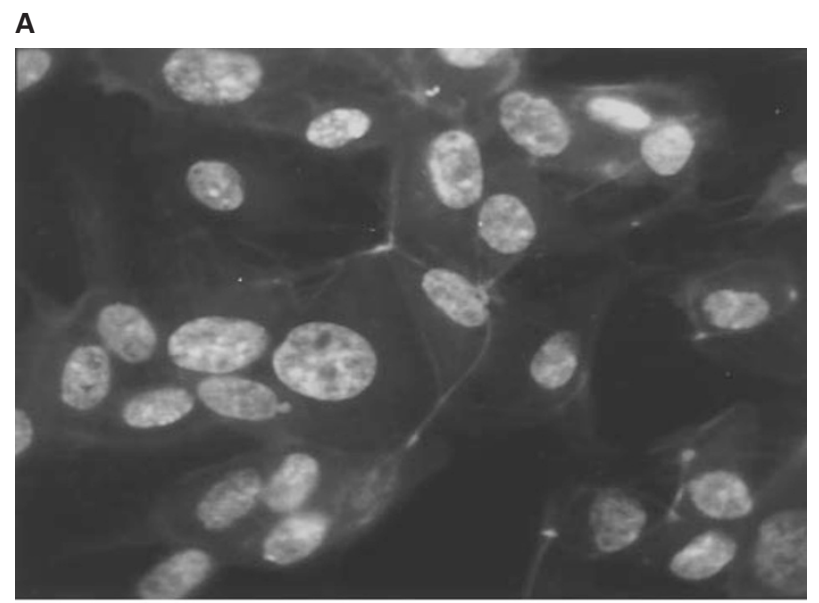

B

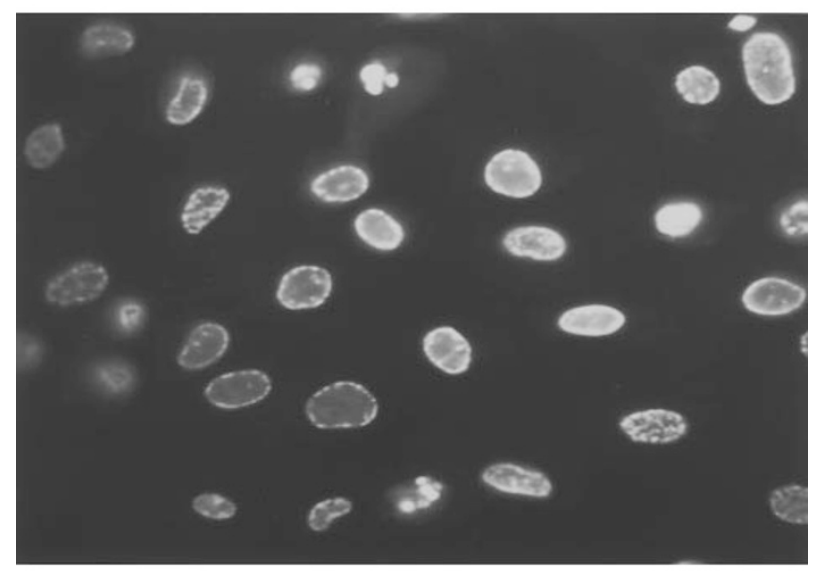

C

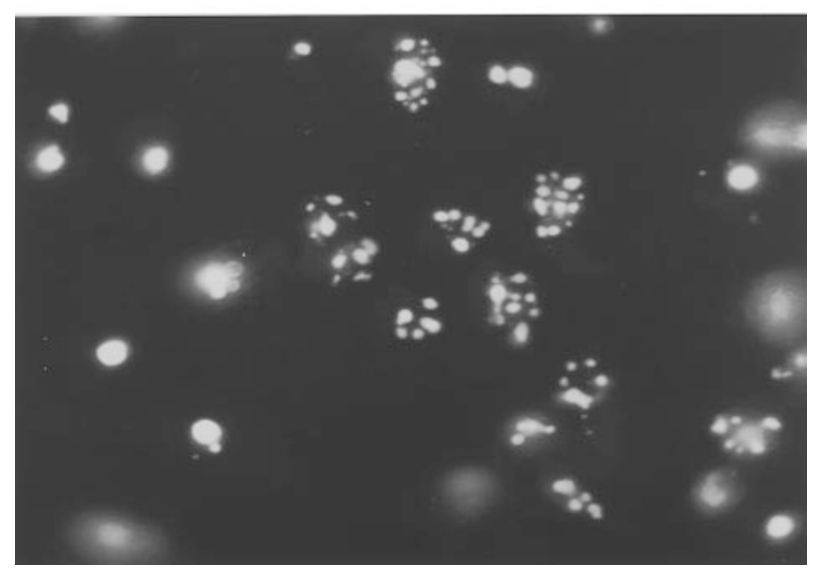

Figure 2 Fluorescence photomicrographs of nuclei of fixed PPTC stained with Hoechst 33458. At the indicated time, PPTC were rinsed with PBS, fixed and stained. Depicted are nuclei of controls (A), of PPTC exposed to $50 \mu \mathrm{M}$ cisplatin for $16 \mathrm{~h}(\mathbf{B})$ and $48 \mathrm{~h}(\mathbf{C})$. Note the nuclear fragmentation, resulting in an intense staining, characteristic for apoptosis, after $48 \mathrm{~h}$ (C) 
Exposure to cisplatin induced a concentration- and timedependent loss of stress fibres, accumulation of F-actin in the junctional ring and finally total depolymerization of $\mathrm{F}$ actin. Moreover, as cells lost their stress fibres, they detached from each other. Most of the cell-cell contact was lost and reduced to a few contacts at the cell surface. Loss of stress fibres was dependent on the concentration of cisplatin and exposure time. When PPTC were exposed to $5 \mu \mathrm{M}$ cisplatin, stress fibres were thinner or lost after $24 \mathrm{~h}$ and the F-actin fibres in the cytosol were thinner and shorter than in control cells (Figure 4b). After a $24 \mathrm{~h}$ exposure to $10 \mu \mathrm{M}$ cisplatin, all stress fibres were lost. Higher concentrations, i.e. 50-250 $\mu \mathrm{M}$, induced total loss of stress fibres within 3-24 h (Figure 4c); yet actin filaments did accumulate at the cortical cytoskeleton. At $500 \mu \mathrm{M}$ cisplatin, PPTC had lost almost all F-actin within $4 \mathrm{~h}$, probably through depolymerization (Figure $4 \mathrm{~d}$ ).

A

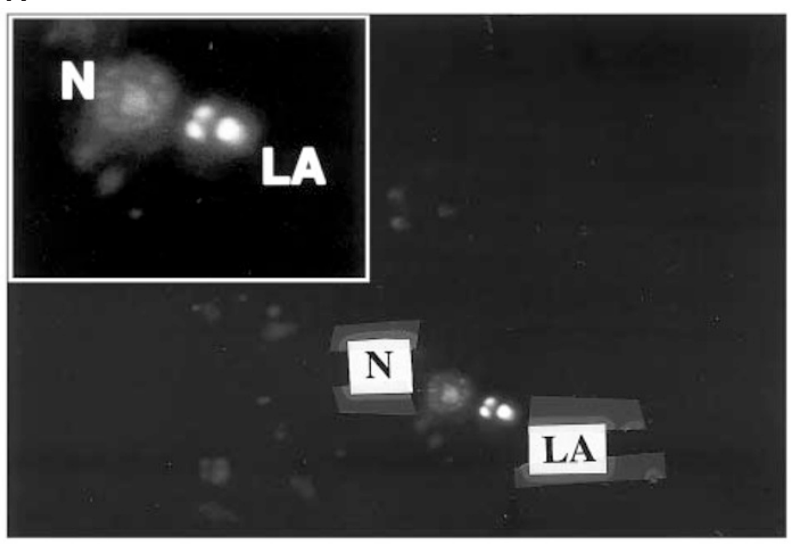

B

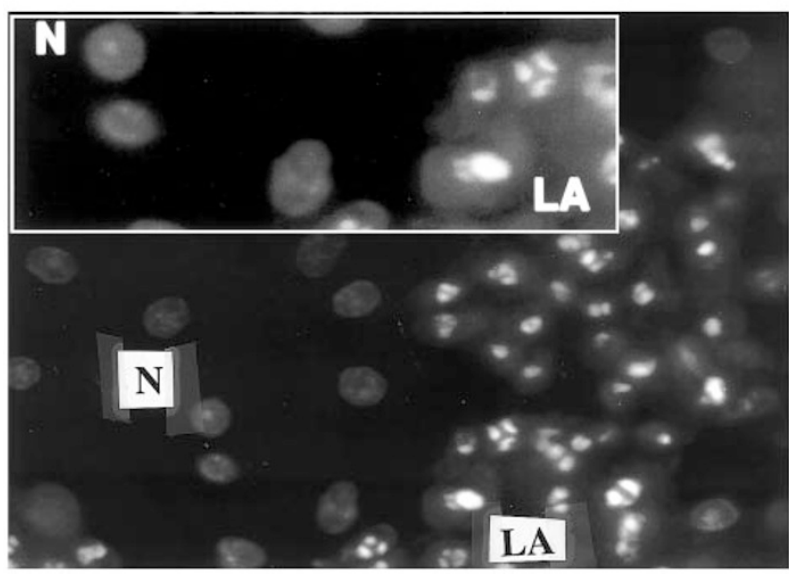

Figure 3 Fluorescence photomicrographs of nuclei of PPTC cells stained with $\mathrm{EtBr}$ and $\mathrm{AcOr}$. Cells were identified based on colour and appearance. Viable cells take up only acridine orange (AcOr), giving them a green colour. Nonviable cells also take up ethidium bromide (EtBr), giving them an orange colour, visible as more intense fluorescence in this picture. In (A) PPTC exposed to $10 \mu \mathrm{M}$ cisplatin are shown. The faintly coloured cells are green (viable). The two most brightly coloured cells are orange, one necrotic $(\mathrm{N})$ and one late apoptotic (LA). Note the condensed chromatin in the apoptotic cell. In (B) monolayers exposed to $50 \mu \mathrm{M}$ cisplatin are shown. All cells in this picture are orange. Both necrotic $(\mathrm{N})$ cells with normal nuclei and late apoptotic (LA) cells are present, with brightly fluorescent condensed chromatin
Interestingly, the effect of cisplatin was specific for actin fibres: we did not find any effect on microtubules within $48 \mathrm{~h}$ (not shown).

\section{Effects of clisplatin on ECM mRNA levels}

Attachment of PTC is mediated via integrins, which connect Factin to the ECM. Since PTC produce their own ECM, we therefore investigated whether cisplatin decreased production of components of the ECM, eventually resulting in celldetachment.

Exposure of PPTC to $10 \mu \mathrm{M}$ cisplatin for $17 \mathrm{~h}$ reduced the mRNA levels of laminin (LN) and fibronectin (FN) to $53 \pm 13$ and $50 \pm 28 \%$, respectively. Higher cisplatin concentrations reduced these levels further (Table 4). The collagen $\alpha_{2}$ type (IV) mRNA (COL) level was not significantly decreased after $17 \mathrm{~h}$, but within $41 \mathrm{~h} 10$ and $50 \mu \mathrm{M}$ cisplatin reduced the level of COL mRNA to $70 \pm 14$ and $30 \pm 20 \%$, respectively (Table 4). All mRNA values were calculated relative to the GAPDH glyceraldehyde 3phosphate dehydrogenase mRNA level (a gene coding for a house-keeping enzyme). The GAPDH mRNA levels did not decrease significantly within $41 \mathrm{~h}$ : the maximal observed decrease was $10 \%$. The observed decreases of the other mRNA's are therefore not due to cell death.

Importantly, the effect on mRNA levels preceded cell detachment: after $17 \mathrm{~h}$ of exposure to $10-50 \mu \mathrm{M}$ cisplatin no significant cell loss could be observed and monolayers were still intact.

Table 2 Effect of various concentrations of cisplatin on viability of adherent PPTC after $48 \mathrm{~h}$ of exposure in culture

\begin{tabular}{|c|c|c|c|c|}
\hline & $\begin{array}{c}\text { Early } \\
\text { apoptotic }\end{array}$ & $\begin{array}{c}\text { Late } \\
\text { apoptotic }\end{array}$ & Necrotic & Viable \\
\hline Cispt $(\mu \mathrm{M})$ & \multicolumn{4}{|c|}{$\%$ of total } \\
\hline Control & $3 \pm 1$ & $1 \pm 0.2$ & $2 \pm 0.2$ & $92 \pm 1$ \\
\hline 5 & $14 \pm 6$ & $23 \pm 1^{*}$ & $9 \pm 3$ & $56 \pm 8 *$ \\
\hline 10 & $3 \pm 1$ & $26 \pm 6^{*}$ & $4 \pm 1$ & $71 \pm 5^{*}$ \\
\hline 50 & $10 \pm 3$ & $48 \pm 10^{*}$ & $25 \pm 14^{*}$ & $37 \pm 6^{*}$ \\
\hline
\end{tabular}

Cells were rinsed with $\mathrm{HH}$ buffer $2 \% \mathrm{BSA}$, stained with $10 \mu \mathrm{M} \mathrm{EtBr}$ and AcOr and analyzed immediately using VIFM. Values are expressed as percentage of total \pm S.E.M. $(n=6)$. * significantly different from control $(P<0.05)$

Table 3 Effect of various concentrations of cisplatin on viability of detached PPTC after $48 \mathrm{~h}$ of exposure in culture

\begin{tabular}{lcccc}
\hline & $\begin{array}{c}\text { Early } \\
\text { apoptotic }\end{array}$ & $\begin{array}{c}\text { Late } \\
\text { apoptotic } \\
\% \text { of total }\end{array}$ & $\begin{array}{c}\text { Necrotic } \\
\text { Cispt }(\mu \mathrm{M})\end{array}$ & \multicolumn{2}{c}{$\begin{array}{l}\text { Viable } \\
\text { Control }\end{array}$} & $10 \pm 1$ & $40 \pm 5$ & $41 \pm 6$ & $6 \pm 2$ \\
5 & $6 \pm 1$ & $48 \pm 1$ & $42 \pm 2$ & $4 \pm 1$ \\
10 & $5 \pm 1$ & $40 \pm 11$ & $51 \pm 12$ & $4 \pm 2$ \\
50 & $6 \pm 1$ & $43 \pm 3$ & $47 \pm 2$ & $2 \pm 0.5$ \\
\hline
\end{tabular}

The monolayers were rinsed with $\mathrm{HH}$ buffer $2 \% \mathrm{BSA}$ and the floating cells were pooled and stained with $10 \mu \mathrm{M} \mathrm{EtBr}$ and AcOr. Cells were analyzed immediately using VIFM. Values are expressed as percentage of total \pm S.E.M. $(n=6)$. *significantly different from control $(P<0.05)$ 


\section{Role of F-actin in cisplatin-induced nuclear changes}

Since cisplatin induced F-actin damage prior to changes in nuclear morphology, we investigated the relationship between F-actin disorganization and apoptosis. All cells treated with any cisplatin concentration that displayed an altered nuclear morphology had lost their F-actin fibres, while in all cells with unchanged nuclei F-actin fibres were still intact. When PPTC were exposed to $20 \mu \mathrm{M}$ cytochalasin $\mathrm{D}$, to disrupt $\mathrm{F}$-actin filaments, nuclear fragmentation was also detected (Figure 5e).

To further study the role of F-actin disorganization, the effect of phalloidin, an F-actin stabilizing compound, on PPTC treated with $5 \mu \mathrm{M}$ cisplatin was tested. At $5 \mu \mathrm{M}$ phalloidin blocked the disappearance of F-actin stress fibres (Figure 5). This was associated with a significant reduction in the extent of cell death, which could be accounted for by inhibition of apoptosis (Table 5).

At $10 \mu \mathrm{M}$ cisplatin, however, phalloidin failed to stabilize F-actin structures in the cells: the F-actin cytoskeleton was damaged in spite of the presence of phailoidin. This was associated with lack of protection against apoptosis.

\section{Effects of cisplatin on the LLC-PK1 cell lines}

Since Bcl-2 is a potent anti-apoptotic protein, capable of preventing apoptosis induced by a variety of triggers in a wide range of cells (Vaux and Weissman, 1993), we investigated if

Table 4 Effect of cisplatin on mRNA levels of ECM components laminin, fibronectin and collagen in PPTC in primary culture

\begin{tabular}{llccc}
\hline $\begin{array}{l}\text { Cispt } \\
(\mu \mathbf{M})\end{array}$ & $\begin{array}{l}\text { Times } \\
\text { (h) }\end{array}$ & Laminin & $\begin{array}{c}\text { Fibronectin } \\
\text { of control }\end{array}$ & Collagen \\
\hline 0 & 17 & $100 \pm 6$ & $100 \pm 9$ & $100 \pm 8$ \\
10 & 17 & $53 \pm 13^{*}$ & $50 \pm 28$ & $87 \pm 20$ \\
25 & 17 & $51 \pm 20^{*}$ & $34 \pm 18^{*}$ & $88 \pm 26$ \\
50 & 17 & $30 \pm 10^{*}$ & $26 \pm 16^{*}$ & $91 \pm 18$ \\
0 & 41 & $100 \pm 8$ & $100 \pm 9$ & $100 \pm 7$ \\
10 & 41 & $65 \pm 6^{*}$ & $59 \pm 30$ & $70 \pm 14^{*}$ \\
25 & 41 & $31 \pm 3^{*}$ & $35 \pm 20^{*}$ & $60 \pm 16^{*}$ \\
50 & 41 & $25 \pm 10^{*}$ & $9 \pm 6^{*}$ & $30 \pm 20^{*}$ \\
\hline
\end{tabular}

mRNA values were calculated relative to $\mathrm{GAPDH}^{1}$ levels and are expressed as percentage + S.E.M. of control cells $(n=3)$. * significantly different from control $(P<0.05)$. ${ }^{1}$ GAPDH mRNA did not decrease significantly within $41 \mathrm{~h}$ : the maximal observed decrease was $10 \%$
A

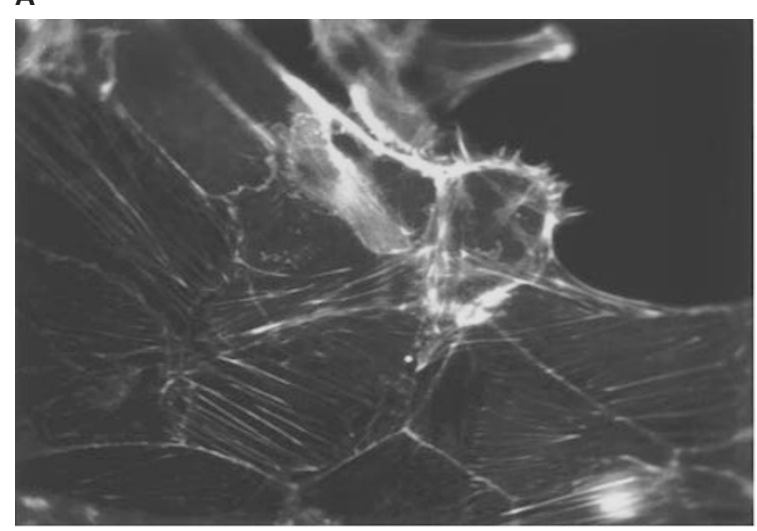

C

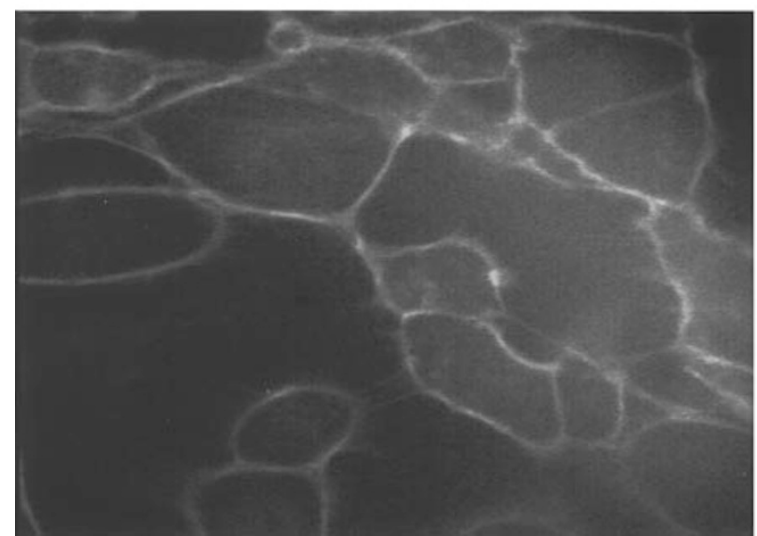

B

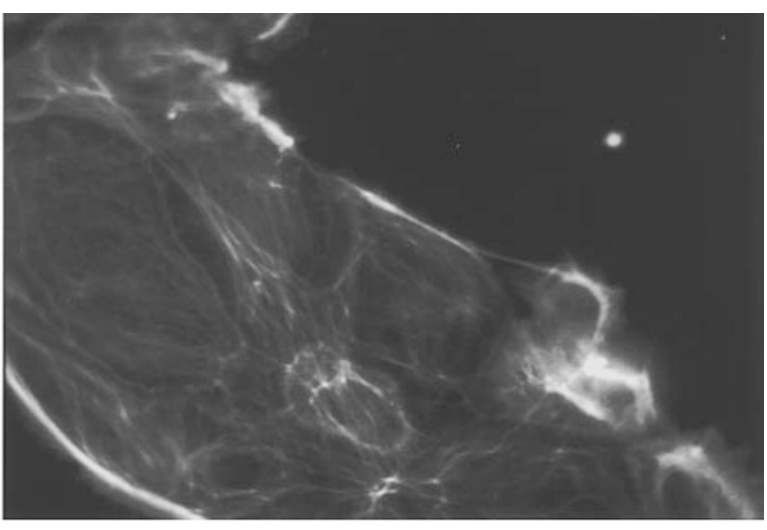

D

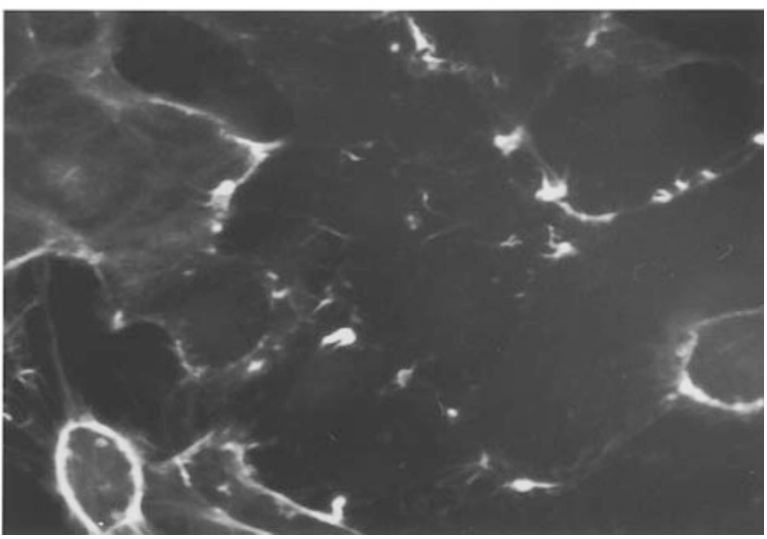

Figure 4 Fluorescence photomicrographs demonstrating the effect of cisplatin on F-actin fibres. PPTC were exposed to various concentrations cisplatin for the indicated times, rinsed with PBS and fixed. Subsequently F-actin was visualized. Control cells (A) display stress fibres. Exposure to $5 \mu \mathrm{M}$ for $24 \mathrm{~h}$ results in thinner fibres than control (B), while $50-500 \mu \mathrm{M}$ results in loss of all fibres after $3-6 \mathrm{~h}(\mathbf{C})$; note the intactness of the junctional actin visible as a ring around the cell. PPTC exposed to $500 \mu \mathrm{M}$ for $4 \mathrm{~h}$ also lost the junctional actin (D) 
Table 5 Effect of $2 \mu \mathrm{M}$ phalloidin on cisplatin-induced cell death of adherent PPTC after $48 \mathrm{~h}$ of exposure to cisplatin in culture in the presence of phalloidin

\begin{tabular}{|c|c|c|c|c|}
\hline \multirow[b]{2}{*}{ Cispt $(\mu \mathrm{M})$} & $\begin{array}{c}\text { Early } \\
\text { apoptotic }\end{array}$ & $\begin{array}{c}\text { Late } \\
\text { apoptotic }\end{array}$ & Necrotic & \multirow[t]{2}{*}{ Viable } \\
\hline & \multicolumn{3}{|c|}{$\%$ of total } & \\
\hline $\begin{array}{l}0 \\
5 \\
10 \\
\text { Plus } 2 \mu \mathrm{M}\end{array}$ & $\begin{array}{r}3 \pm 1 \\
14 \pm 6 \\
3 \pm 1 \\
\text { alloid }\end{array}$ & $\begin{array}{c}1 \pm 0.2 \\
23 \pm 1^{*} \\
26 \pm 6^{*}\end{array}$ & $\begin{array}{l}2 \pm 0.2 \\
9 \pm 3 \\
4 \pm 1\end{array}$ & $\begin{array}{l}92 \pm 1 \\
56 \pm 8^{*} \\
61 \pm 5^{*}\end{array}$ \\
\hline $\begin{array}{l}0 \\
5 \\
10\end{array}$ & $\begin{array}{l}5 \pm 2 \\
7 \pm 3 \\
1 \pm 0.5\end{array}$ & $\begin{array}{c}1 \pm 0.2 \\
10 \pm 1^{* \#} \\
22 \pm 8^{*}\end{array}$ & $\begin{array}{c}7 \pm 0.2 \\
11 \pm 3^{*} \\
9 \pm 1\end{array}$ & $\begin{array}{l}90 \pm 4 \\
72 \pm 3^{\star \#} \\
61 \pm 9^{*}\end{array}$ \\
\hline
\end{tabular}

Cells were rinsed with $\mathrm{HH}$ buffer $2 \% \mathrm{BSA}$, stained with $\mathrm{EtBr}$ and $\mathrm{AcOr}$ and analyzed immediately using VIFM. Values are expressed as percentage of total \pm S.E.M. $(n=6)$. *significantly different from control, " significantly different from exposure to cisplatin without phalloidin $(P<0.05)$

the $b c /-2$ gene product could protect renal cells from cisplatininduced toxicity. We used an LLC-PK1 cell overexpressing $\mathrm{Bcl}-2$ in a zinc-inducible system ('BCL2'), and a neomycin resistance-transfected PK1 cell line as control ('NEO').

Before studying the role of $\mathrm{Bcl}-2$ in cisplatin toxicity in LLC-PK1 cells, we repeated all experiments described above for PPTC in the LLC-PK1 tell lines, in order to confirm that cisplatin exerted the same effects in both cell systems. Cisplatin showed essentially the same effects on cell adhesion and viability, damage to the F-actin cytoskeleton and extent of apoptosis and necrosis. The only difference was observed in expression of the mRNA encoding for collagen: in contrast to the lack of effect in PPTC, cisplatin reduced COL mRNA levels in the LLC-PK1 cell lines to the same extent as the levels of mRNA encoding for FN (Figure 6).

\section{Overexpression of Bcl-2 in the LLC-PK1 cell line}

Exposure to $100 \mu \mathrm{M} \mathrm{ZnSO}$, required to induce Bcl-2 in the BCL2 cell line, completely prevented the cisplatin-induced changes in nuclear morphology in the three LLC-PK1 cell lines. Therefore, this did not allow conclusions as to the role of $\mathrm{Bcl}-2$. To avoid this, Bcl-2 induction was performed by preincubation of the cells with $100 \mu \mathrm{M} \mathrm{ZnSO} 4$ for $48 \mathrm{~h}$; subsequently the cells were exposed to cisplatin after removal of $\mathrm{ZnSO}_{4}$.

In order to confirm that $\mathrm{ZnSO}_{4}$ pretreatment did result in an upregulation of $\mathrm{Bcl}-2$ after $\mathrm{ZnSO}_{4}$ removal, we analyzed the $\mathrm{Bcl}-2$ content after removal of $\mathrm{ZnSO}_{4}$. Exposure of the $\mathrm{BCL} 2$ cell line to $100 \mu \mathrm{M} \mathrm{ZnSO}_{4}$ for $48 \mathrm{~h}$ resulted in an increased amount of the $25 \mathrm{kDa} \mathrm{Bcl}-2$ protein after $24-$ $48 \mathrm{~h}$ (Figure 7: lanes 9-12); the Bcl-2 level increased to $250 \pm 22 \%$ of control at $48 \mathrm{~h}$. After removal of $\mathrm{ZnSO}_{4}, \mathrm{Bcl}-2$ slowly declined, but it was still elevated in comparison with control cells after $48 \mathrm{~h}$ (Figure 7: lanes 13,14): after $24 \mathrm{~h}$ the $\mathrm{Bcl}-2$ content was $200 \pm 18 \%$ and after $48 \mathrm{~h}$ it was $157 \pm 12 \%$.

\section{Prevention of nuclear fragmentation by $\mathrm{Bcl}-2$}

Exposure of the control LLC-PK1 cell line and the control transfected 'NEO' cell line to $50 \mu \mathrm{M}$ cisplatin for $48 \mathrm{~h}$ subsequent to the $\mathrm{ZnSO}_{4}$ treatment gave identical results as in PPTC: $58 \pm 10 \%$ of the cells displayed a fragmented nuclus. After staining the condensed and fragmented nuclei were visible as intensely fluorescent clumps (Figure 8b). EtBr and AcOr staining revealed that the ratio early/late apoptotic cells was not changed after $\mathrm{ZnSO}_{4}$ pre-treatment (not shown), demonstrating that this $\mathrm{ZnSO}_{4}$ pre-incubation did not interfere with the nuclear fragmentation.

Induction of $\mathrm{Bcl}-2$ by $\mathrm{ZnSO}_{4}$ in the $\mathrm{BCL} 2$ cell line resulted in a reduction of the percentage of apoptotic cells from $67-20 \%$ (Figure 9). This protection from cisplatininduced apoptosis is illustrated in Figure 7c. However, the protection by $\mathrm{Bcl}-2$ was not complete since $20 \pm 5 \%$ of the cells of the monolayer still displayed a degraded nucleus, indicative of (early and late) apoptosis (Figure 8d). The fact that protection is not observed in all cells may be due to the fact that the amount of $\mathrm{Bcl}-2$ protein started to decrease immediately after the removal of $\mathrm{ZnSO}_{4}$, so that some cells may in fact be below a critical minimum level of $\mathrm{Bcl}-2$ protein.

\section{Effect of Bcl-2 induction on cisplatin-induced $\mathrm{F}$-actin damage and ECM production}

To test whether $\mathrm{Bcl}-2$ cytoprotection was related to protection against F-actin rearrangement we investigated the effect of $\mathrm{Bcl}-2$ overexpression on cisplatin-induced $\mathrm{F}$-actin damage.

After preincubation with $100 \mu \mathrm{M} \mathrm{ZnSO}$, the cisplatininduced $\mathrm{F}$-actin damage in BCL2 cells was identical to the damage in control cells and in BCL2 cells without $\mathrm{ZnSO}_{4}$ pre-incubation (Figure 10), demonstrating that Bcl-2 overexpression had no effect on cisplatin-induced F-actin damage. Similarly, expression of Bcl-2 did not affect the cisplatin induced effects on ECM production (Figure 6).

\section{Discussion}

This study provides evidence that F-actin damage may contribute to cisplatin-induced nephrotoxicity. Low concentrations of cisplatin $(5-10 \mu \mathrm{M})$, that did not induce necrosis, caused the loss of stress fibres in PPTC and LLC-PK1 cells within $24 \mathrm{~h}$; higher concentrations induced more severe effects in a shorter time. Since F-actin is continuously formed and degraded, cisplatin might affect either process. Zeng et al (1996) showed that $10-300 \mu \mathrm{M}$ cisplatin merely inhibited polymerization, suggesting that at the lower concentration of cisplatin in our setting (and also in vivo), inhibition of polymerization and severing of F-actin filaments into smaller ones, are the main causes of cisplatin-induced F-actin damage. This is confirmed by the observation that only at higher concentrations (50$500 \mu \mathrm{M}$ cisplatin) an increase in soluble G-actin was observed, presumably caused by complete depolymerization (data not shown).

F-actin damage may contribute to nephrotoxicity in two ways. Firstly, F-actin damage may cause an increased monolayer permeability, as shown for mouse PTC in culture with a loss of stress fibres (Kroshian et al, 1994). Secondly, the cytoskeleton, especially the F-actin network, has been implicated in maintenance of cell attachment in a variety of 
epithelia; it interacts with cell surface adhesion molecules at homotypic and cell-matrix adhesion sites, called focal adhesions (van de Water et al, 1994; Fish and Molitoris, 1994b). Thus F-actin damage can cause cell detachment. In our laboratory, a relation between F-actin damage and detachment of rat PTC both in vitro and in vivo, has been demonstrated (Van de Water et al, 1994). Since F-actin damage occurred prior to cell detachment, it may play an important role in cisplatin-induced detachment of PPTC and LLC-PK1 cells. This is supported by the observation that cytochalasin D mimicked cisplatin-induced effects on Factin organization and cell attachment.

B

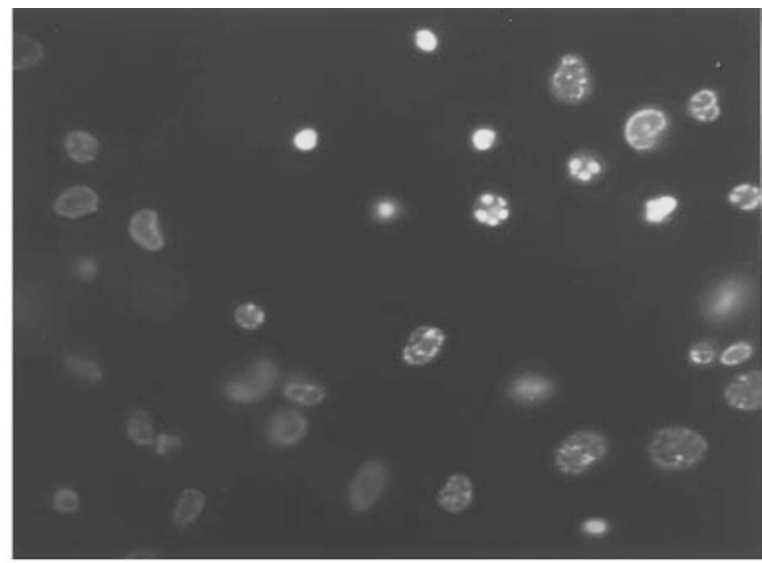

D

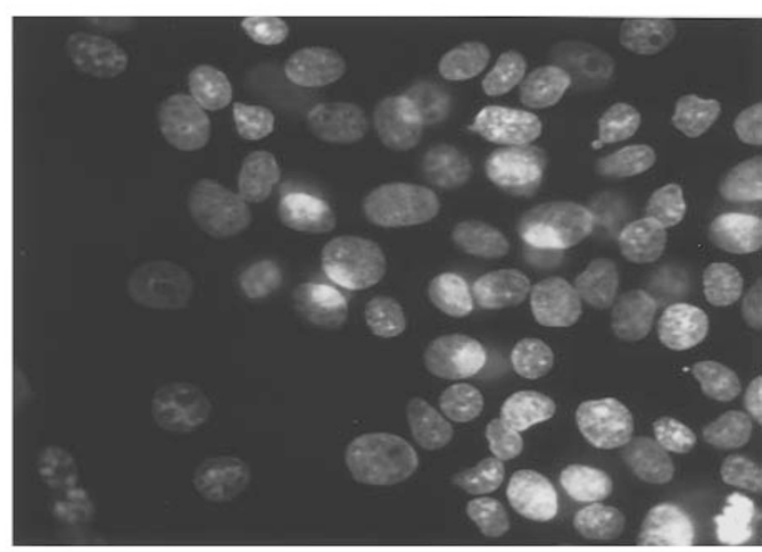

E

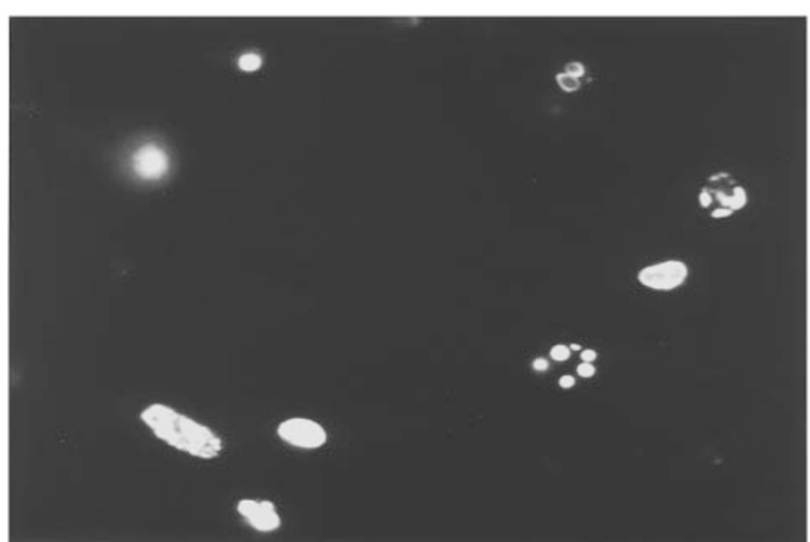

Figure 5 The effect of phalloidin on F-actin and apoptosis in PPTC. The fluorescence photomicrographs illustrate the relation between F-actin fibres and onset of apoptosis in PPTC. PPTC exposed to $5 \mu \mathrm{M}$ cisplatin for $48 \mathrm{~h}$ loose stress fibres (A) and in some nuclei chromatin degradation is observed (B). PPTC exposed to cisplatin $+2 \mu \mathrm{M}$ phalloidin, preserve stress fibres (C), which prevents the nucleus from chromatin degradation (D). In (E) nuclei of PPTC exposed to $20 \mu \mathrm{M}$ cytochalasin $\mathrm{D}$ are shown displaying nuclear fragmentation 
Cell detachment may also be caused by a direct effect on the integrins or ECM. Since cisplatin is known to inhibit RNA and protein synthesis (Kondo et al, 1995) and Goligorsky and co-workers (Gallit et al, 1993) showed that integrin levels were not reduced in detached cells, we hypothesized that a reduced ECM expression might contribute to renal cell detachment by cisplatin. Our results show that exposure of PPTC and LLC-PK1 cells to sublethal concentrations of cisplatin reduced the expression of mRNA encoding for fibronectin, laminin, and collagen IV $\alpha_{2}$. While in PPTC COL mRNA levels were not affected within $17 \mathrm{~h}$, in LLC-PK1 cells COL mRNA levels were decreased at this time-point. The reason for this difference between primary cultured PTC and the LLC-PK1 cells remains unclear and may be a consequence of the immortalization of the LLC-PK1 cells. The reduction in mRNA levels preceded changes in cell morphology and detachment, implying that reduced mRNA production of ECM components with subsequent reduced integrin binding may contribute to cisplatin-induced renal cell detachment. Since the mRNA levels are calculated relative to GAPDH levels, a housekeeping gene, which did not decrease significantly during the experiment, we conclude that the cisplatin-induced reduction in mRNA levels is not just a consequence of cell death, cell detachment or overall non-specific reduction of mRNA.
A

FN: PK1

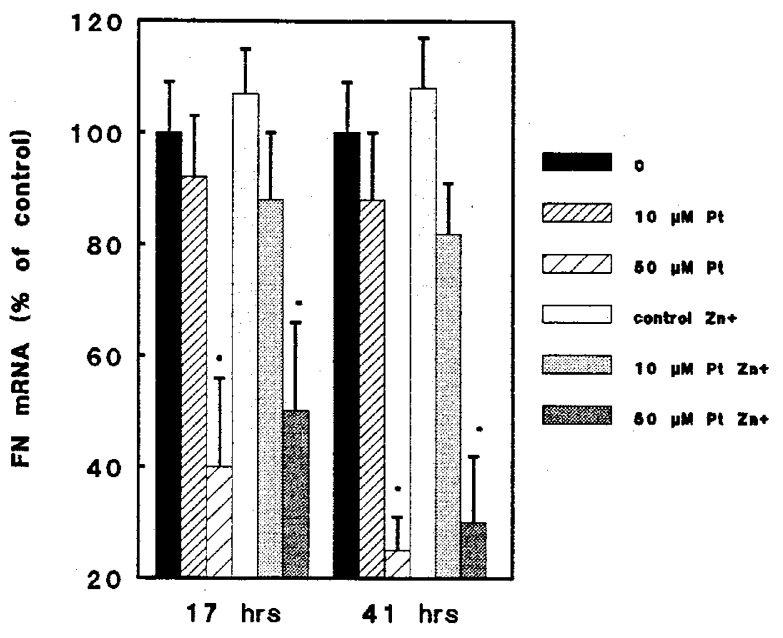

C

col : PK1

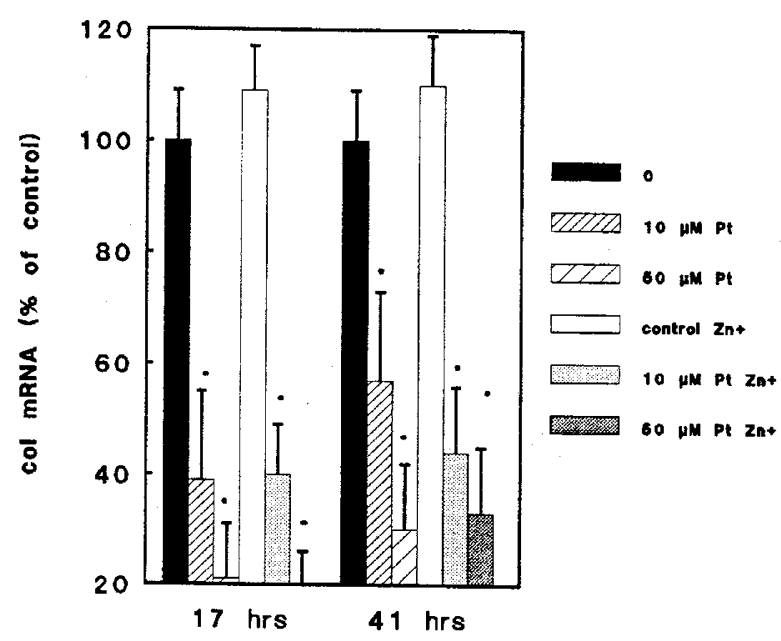

$\mathrm{B}$

FN: BCL2
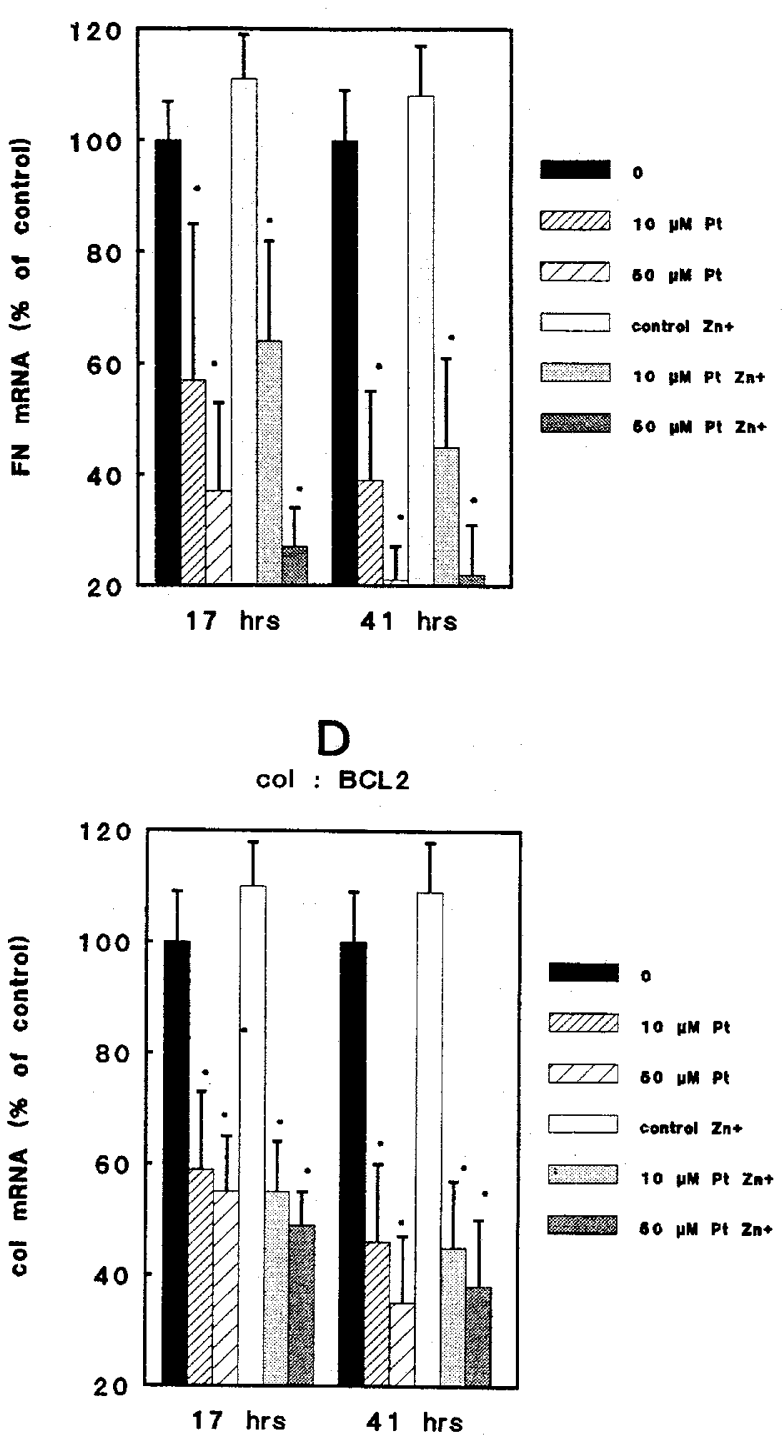

Figure 6 Effects of cisplatin on mRNA expression of collagen $\alpha_{2}$ type (IV) (COL) and fibronectin (FN) in LLCPK1 cells, with or without pretreatment with $100 \mu \mathrm{M}$ $\mathrm{ZnSO}_{4}$ to induce Bcl-2 in the BCL2 cells. mRNA values were calculated relative to GAPDH (which decreased less than $10 \%$ within $41 \mathrm{~h}$ ) and are expressed as percentage of control \pm S.E.M. ( $n=3$ ). significantly different from control. Shown are: fibronectin mRNA in PK1 (A) and BCL2 (B) cells; collagen mRNA levels in PK1 (C) and BCL2 (D) cells 
However, the synthesis of other proteins may be inhibited as well.

The ECM-integrin contact is essential for prevention of apoptosis known as 'anoikis' (Frisch et al, 1996; Ruoslahti, 1996) by increasing levels of Bcl-2 in the case of $\alpha 5, \beta 1$

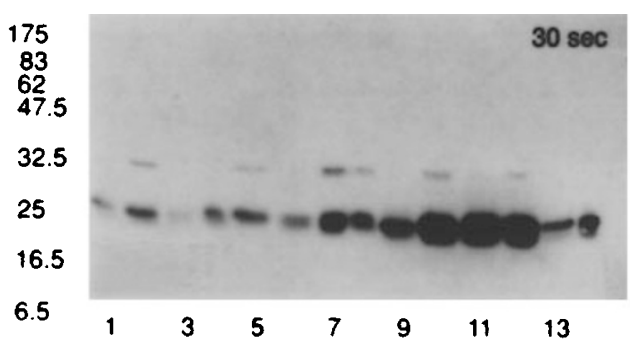

Figure 7 Immunoblot analysis of bcl-2 in control transfected (NEO) and bcl-2 transfected (BCL2) cells during and after induction with $100 \mu \mathrm{M} \mathrm{ZnSO}_{4}$ for $48 \mathrm{~h}$. Start of $\mathrm{ZnSO}_{4}$ treatment is $\mathrm{t}=0$, and $(48+24)$ is the notation for $48 \mathrm{~h} \mathrm{ZnSO}_{4}$ treatment and $\mathrm{Bcl}-2$ detection $24 \mathrm{~h}$ after removal of $\mathrm{ZnSO}_{4}$. Lanes 1-2: NEO $\mathrm{Zn}[-] \mathrm{t}=0$, 48. Lanes 3-4: NEO $\mathrm{Zn}[+] \mathrm{t}=0$, 48. Lane 5: NEO $\mathrm{Zn}[+] \mathrm{t}=48+24$ Lanes 6-8: BCL2 Zn[-] t=0, 24, 48. Lanes 9-12: BCL2 $Z n[+] t=24,24,48,48$ Lanes 13-14: BCL2 Zn[+] $t=48+24,48+48$

\section{A}

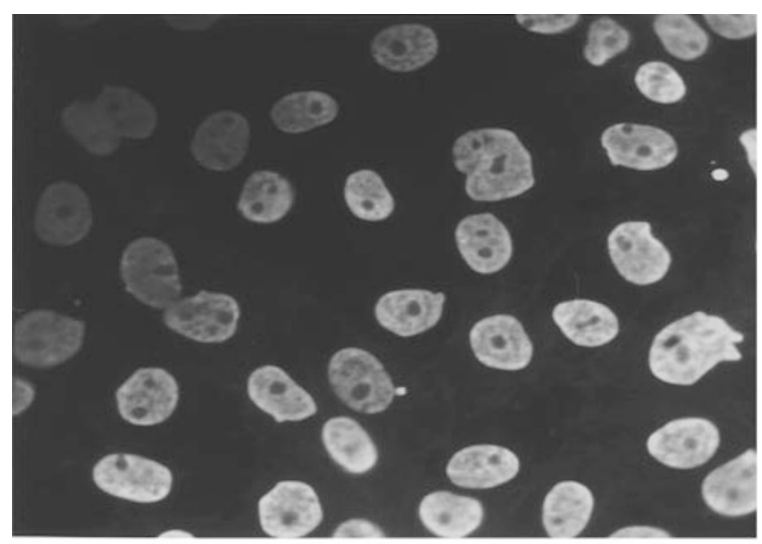

C

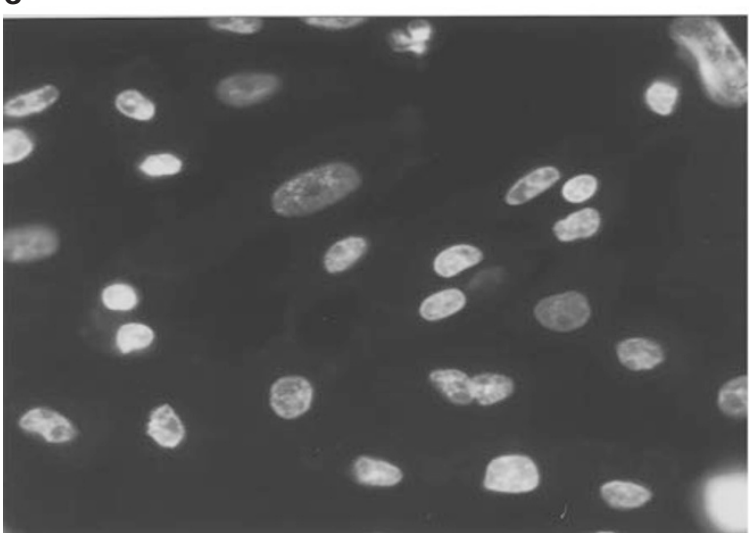

integrin (Zhang et al, 1995). In concordance, we found that cisplatin induced loss of $\mathrm{F}$-actin fibres, and reduction of mRNA levels encoding for ECM components was accompanied by apoptosis.

Our data provide evidence that the onset of cisplatininduced nuclear fragmentation is, at least in part, dependent on cytoskeletal damage. First of all, F-actin damage occurred prior to the changes in nuclear morphology. Secondly, prevention of F-actin damage in viable cells by phalloidin prevented the formation of fragmented nuclei. Finally, control experiments with cytochalasin $\mathrm{D}$ that specifically induces $\mathrm{F}$ actin damage caused similar nuclear fragmentation. This is in concordance with a relation between F-actin and apoptosis described for rat PTC (van de Water et al, 1996) and neutrophils (Brown et al, 1997).

Exactly how $\mathrm{F}$-actin damage is involved in the onset of apoptosis remains to be elucidated. Zhang et al (1995) have shown that some integrins can suppress apoptosis via the Bcl-2 pathway. Moreover, Hsu et al (1997) showed that subcellular localization of members of the Bcl-2 family changed during apoptosis. Based on this as well as on our present results it could be postulated that F-actin is involved in the maintenance of the concentration or subcellular

\section{B}

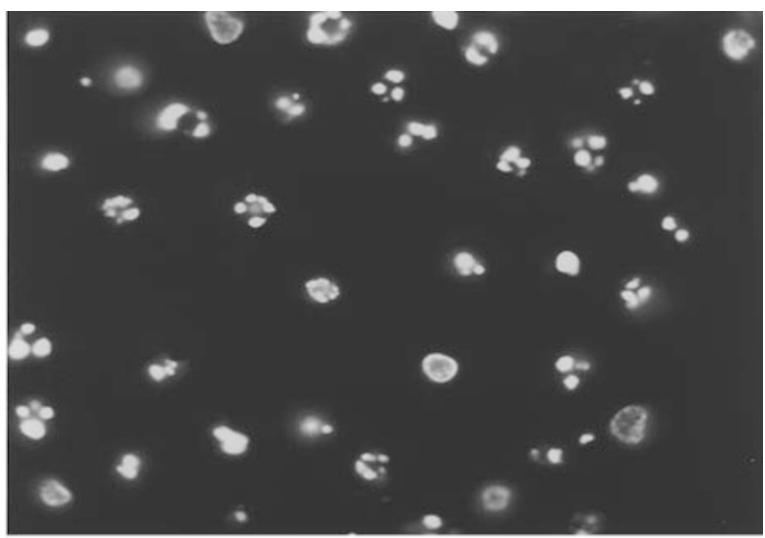

D

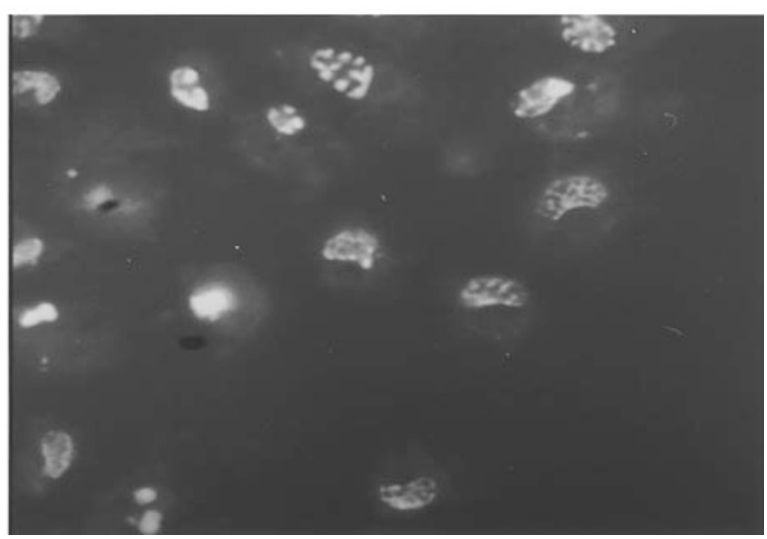

Figure 8 Fluorescence photomicrographs of nuclei of PK1 and BCL2 cells stained with Hoechst 33458 . After $48 \mathrm{~h}$ of exposure to $100 \mu \mathrm{M}$ ZnSO 4 , cells were exposed to 0 (control) or $50 \mu \mathrm{M}$ cisplatin for $48 \mathrm{~h}$, rinsed with PBS, fixed and stained. Depicted are control (A), nuclei of PK1 cells, PK1 cells exposed to $50 \mu \mathrm{M}$ cisplatin (B) and BCL2 cells exposed to $50 \mu \mathrm{M}$ cisplatin after induction of bcl-2 (C). Note the condensation of the chromatin and degradation, resulting in an intense staining, characteristic for apoptosis in $\mathbf{B}$, which was observed in all cell lines. Prevention of apoptosis by bcl-2 (C) was not complete since in some parts of BCL2 cells exposed to cisplatin after $\mathrm{ZnSO}_{4}$ exposure, apoptotic cells were observed (D) 
distribution of members of the Bcl-2 family, when Bcl-2 is expressed at physiological levels. However, although Haidar et al (1997) demonstrated that drugs that disrupt cytoskeletal integrity cause apoptosis via inactivation of Bcl-2; they also showed that cisplatin does not use this Bcl-2 pathway. This favours the hypothesis that apoptosis associated with F-actin damage is the consequence of altered integrin signalling. Clearly, further studies are needed to confirm this hypothesis.

Prevention of cisplatin-induced F-actin damage suppressed nuclear fragmentation, but prevention of nuclear fragmentation by $\mathrm{Bcl}-2$ occurred without reduction of the damage to F-actin. Therefore, it can be postulated that F-actin damage is an early, and nuclear degradation a later process of the 'apoptotic' pathway. Thus, overexpression of Bcl-2 prevented apoptosis without affecting the 'upstream', $\mathrm{F}$-actin damage signal. In spite of the functional relation between F-actin damage and apoptosis, our results also reveal that damage does not necessarily cause apoptosis, since also non-apoptotic, viable cells detached.

Because of the physiological similarities of the kidneys of pig and man, the results obtained with PPTC seem more relevant to man than results obtained from rodent models. The results regarding cisplatin-induced cell detachment and apoptosis may have clinical relevance, since plasma levels of approximately $10 \mu \mathrm{M}$ cisplatin were reported for patients at the end of a $6 \mathrm{~h}$ infusion of $80 \mathrm{mg} / \mathrm{m}^{2}$ (Fish et al, 1994a). This study demonstrates that at this concentration, cisplatin induces cell detachment and changes in nuclear morphology of renal cells, suggesting a contribution of these processes to renal dysfunction, associated with cisplatin therapy.

In conclusion, we demonstrated that cisplatin induces damage to the F-actin cytoskeleton and reduces expression of mRNA encoding forCOL, $F N$ and $L N$ in renal cells.

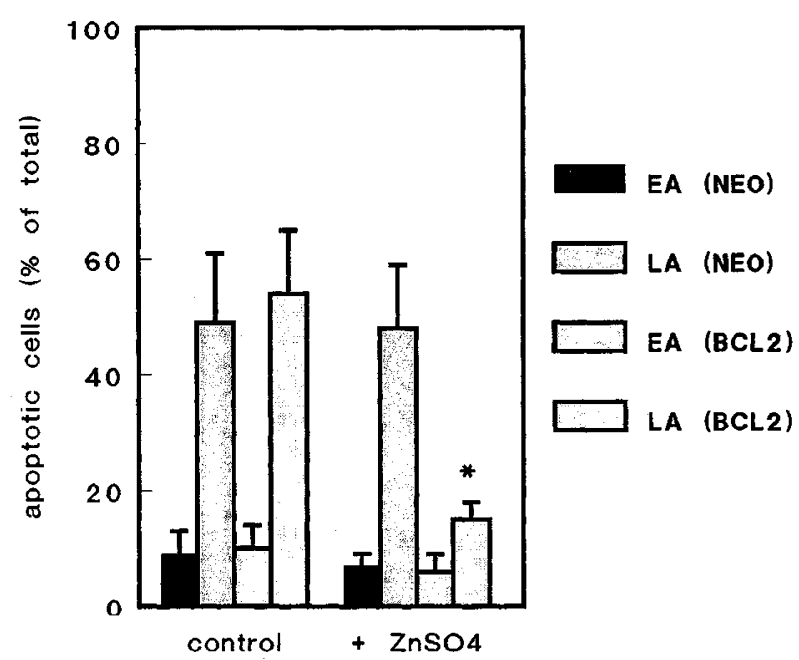

Figure 9 Effect of preincubation with zinc $(100 \mu \mathrm{M} \mathrm{ZnSO}, 48 \mathrm{~h})$ to induce bcl-2 in BCL2 cells, on apoptosis induced by cisplatin $(50 \mu \mathrm{M}, 48 \mathrm{~h})$. NEO transfected and control LLC-PK1 cell lines were used as control. Similar results were obtained in both cell lines, therefore only NEO is depicted. Values are determined in adherent cells and are percentage apoptotic cells of total, expressed as mean \pm S.E.M. $(n \geqslant 5, P \leqslant 0.05)$, significantly different from cells without $\mathrm{ZnSO}_{4}$. EA: early apoptotic, LA: late apoptotic
Together, these effects may cause cell detachment and changes in nuclear morphology associated with apoptosis. This can be overcome at low concentrations by preventing $\mathrm{F}$-actin damage and by overexpression of $\mathrm{Bcl}-2$ at all

A

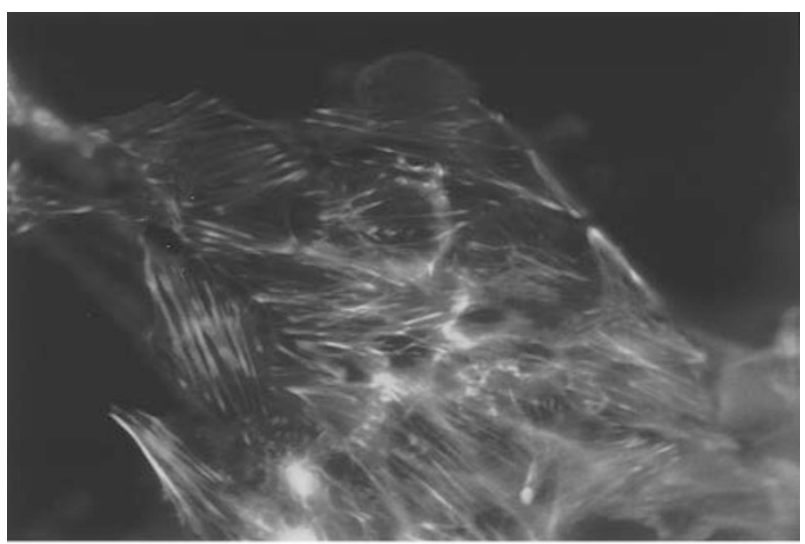

B

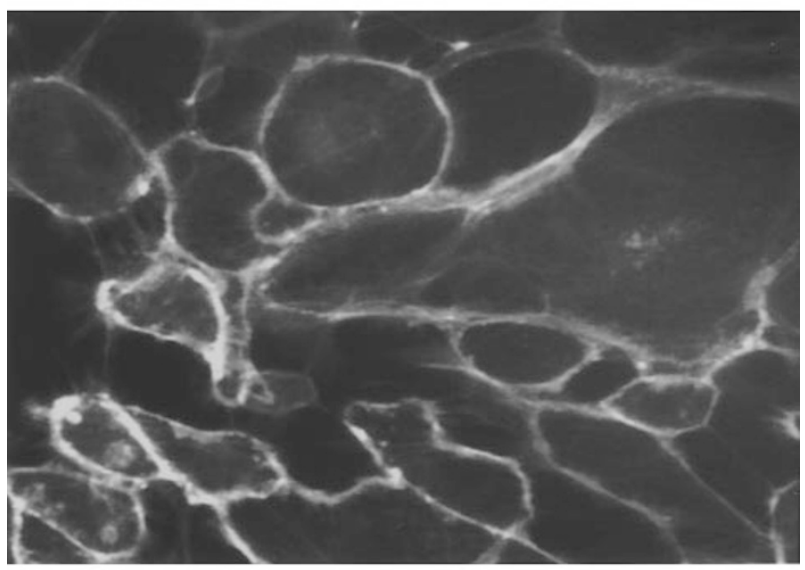

C

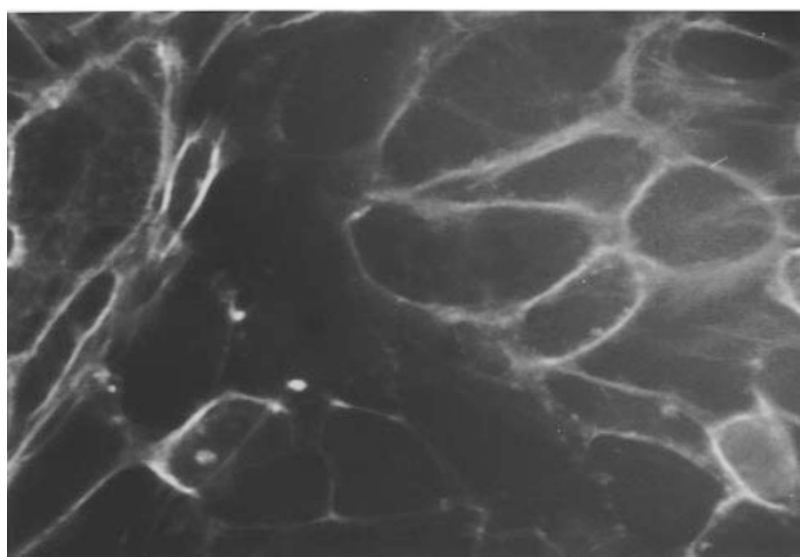

Figure 10 Fluorescence photomicrographs demonstrating the effect of cispiatin on F-actin fibres. BCL2 cells were exposed to $50 \mu \mathrm{M}$ cisplatin for $48 \mathrm{~h}$, rinsed with PBS and fixed. Subsequently F-actin was visualized. Control cells (A) display stress fibres. Exposure to $50 \mu \mathrm{M}$ cisplatin ( $48 \mathrm{~h}$ ) causes loss of F-actin stress fibres (B). After induction of bcl-2 in the BCL2 cells, subsequent exposure to cisplatin still causes loss of stress fibres (C) 


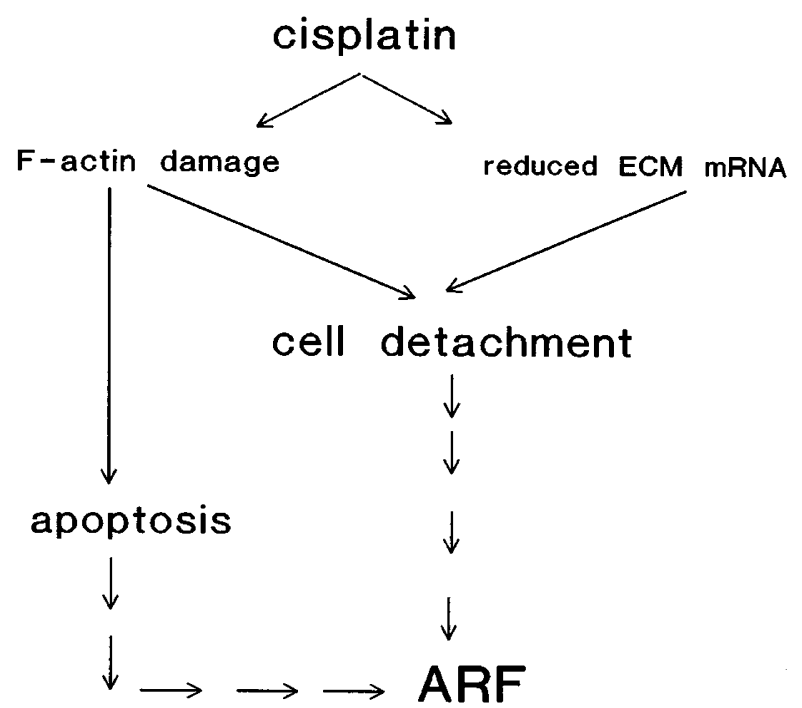

Figure 11 Scheme of cisplatin-induced effects on renal cells causing cell detachment, increased tubular permeability eventually leading to acute renal failure

concentrations inducing nuclear fragmentation (i.e. 5$50 \mu \mathrm{M})$.

In vivo, both processes may eventually result in tubules with denuded basement membranes and thus contribute to cisplatin-induced renal dysfunction and $A R F$, as is schematically depicted in Figure 11.

\section{Materials and Methods}

\section{Chemicals}

Bovine serum albumin (BSA), collagenase (EC 3.4.24.3) (from Clostridium histolyticum), cis-diamine-dichloroplatinum (II) (cisplatin), ethyleneglycol-bis-( $\beta$-aminoethylether)-N,N,N',N,-tetraacetic acid (EGTA), sodium deoxycholate (DOC), phenylmethylsulfonyl fluoride (PMSF), phalloidin, trypsin inhibitor type II-T (from turkey egg white) ethidium bromide $(\mathrm{EtBr})$ were from Sigma Chemical Co. (St Louis, MO, USA). N-2-hydroxyethylpiperazine- $\mathrm{N}^{\prime}$-2-ethanesulfonic acid (HEPES), sodium pyruvate, RNAse A, nonidet P-40 (NP-40), sodium pyruvate and monoclonal mouse anti BCL-2 (clone 104) and proteinase $\mathrm{K}$ were obtained from Boehringer Mannheim (Mannheim, Germany). Nycodenz (lohexol) was from Nycomed AS (Oslo, Norway). Acridine orange (AcOr), bodipy-phalloidin and propidium iodide (PI) were from Molecular Probes (Eugene, OR, USA). Peroxidase-conjugated antimouse IgG was from Jackson Immuno Research Labs (West Grove, PA, USA). The enhanced chemiluminescence method (ECL) kit was from Amersham Laboratories (Buckinghamshire, UK). Fluorescentlabelled goat anti-mouse IgG was from Caltag Laboratories (San Francisco, CA, USA).

Chemicals for cell culture Defined bovine calf serum (BCS) (supplemented) was from HyClone Laboratories Inc. (Logan, UT, USA). Penicillin G was from Gist Brocades (Delft, The Netherlands). Ciprofloxacin from Bayer AG (Leverkusen, Germany). Amphotericin B from Bristol-Myers Squibb BV (Rijswijk, The Netherlands). All other chemicals used for cell culture were from Sigma.

\section{Isolation and culture of porcine proximal tubular cells (PPTC)}

Cell isolation of PPTC was performed as described before (Kruidering et al, 1997). The final cell preparation, lacking distal tubular and endothelial cells (Kruidering et al, 1994), had a viability of over $90 \%$ and contained routinely $90 \%$ cells that were positive for $\gamma$-glutamyl transpeptidase (GGT), indicating that they were proximal tubular cells.

The cells were cultured in Dulbecco's modified eagle's medium

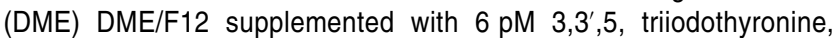
$5 \mathrm{mg} / \mathrm{l}$ transferrin, $10 \mu \mathrm{g} / \mathrm{l}$ epidermal growth factor, $100 \mathrm{nM}$ hydrocortisone, $28 \mathrm{nM}$ prostaglandin $E_{1}, 29 \mathrm{nM}$ sodium selenite, $1 \mathrm{nM}$ retinoic acid, 100 units/l insulin, $50 \mathrm{nM}$ dexamethasone, $10^{5}$ units/l penicillin G, $2.5 \mathrm{mg} /{ }^{1}$ amphotericin $\mathrm{B}, 4 \mathrm{mg} / \mathrm{l}$ ciprofloxacin, $2 \mathrm{mM} \mathrm{L}$ glutamine, $1.1 \mathrm{mM}$ pyruvate and $10 \%$ serum as described previously (Kruidering et al, 1994). The cultures were maintained at $37^{\circ} \mathrm{C}$ in a humidified $95 \%$ air $/ 5 \% \mathrm{CO}_{2}$ atmosphere. The medium containing $10 \%$ (v/v) serum and hormones was replaced by serum-free medium with hormones after reaching confluence; the latter was replaced every 2 days. Cells were cultured on collagen $(40 \mu \mathrm{g} / \mathrm{ml}$ from rat tail, Type I Sigma) coated coverslips in six well culture plates for histochemistry and in collagen coated $75 \mathrm{~cm}^{2}$ culture flasks for RNA isolation.

Growth and morphology of the cells were monitored using a Nikon TMS Reversed Microscope equipped with phase contrast optics. PPTC were used $1-2$ days after reaching confluence $(5-6$ days after plating)

Morphological, biochemical and immunohistochemical characterization demonstrated that the cells were of proximal tubular origin and that the PPTC retained a brush border as well as GGT and alkaline phosphatase activity in culture; they expressed keratin and FX1A (Kruidering et al, 1994).

\section{Cell lines}

Three cell lines were used: the LLC-PK1 cell line, designated PK1; a LLC-PK1 cell line transfected with a control vector, carrying only the neomycin resistance, designated 'NEO'; and a LLC-PK1 cell line which was transfected with a human $b c l-2$ construct (Vaux and Weissman, 1993), cloned in the pVZ1 vector (Henikoff and Eghtedarzadeh, 1987) with a zinc-inducible promotor, designated 'BCL2'. The cell lines were cultured in DME supplemented with $10^{5} \mathrm{U} / \mathrm{l}$ penicillin, $5 \mu \mathrm{g} / \mathrm{ml}$ streptomycin, $100 \mu \mathrm{g} / \mathrm{ml}$ geneticin and $10 \%(\mathrm{v} / \mathrm{v})$ serum. The cultures were maintained at $37^{\circ} \mathrm{C}$ in a humidified $95 \%$ air $/ 5 \% \mathrm{CO}_{2}$ atmosphere. Experiments were performed with passages 203-211. Growth and morphology of the cells were monitored using a Nikon TMS Reversed Microscope equipped with phase contrast optics. For fluorescence analysis of the nucleus and cytoskeleton, cells were cultured on collagen-coated coverslips, and for RNA isolation in collagen coated $75 \mathrm{~cm}^{2}$ culture flasks.

\section{Detection of $\mathrm{Bcl}-2$ by gel electrophoresis and immunoblotting}

In order to induce $\mathrm{Bcl}-2$ expression, confluent monolayers of cells cultured in $6 \mathrm{~cm}$ culture dishes were exposed to $6 \mathrm{ml} 100 \mu \mathrm{M} \mathrm{ZnSO}_{4}$ in DME for $24-48 \mathrm{~h}$ in a humidified $95 \%$ air $/ 5 \% \mathrm{CO}_{2}$ atmosphere. After exposure, the cells were washed four times with $10 \mathrm{ml} \mathrm{Hanks-HEPES}$ buffer $\mathrm{pH} 7.4$, consisting of $137 \mathrm{mM} \mathrm{NaCl}, 5 \mathrm{mM} \mathrm{KCl}, 0.8 \mathrm{mM} \mathrm{MgSO}_{4}$, $0.4 \mathrm{mM} \mathrm{Na}_{2} \mathrm{HPO}_{4}, 0.4 \mathrm{mM} \mathrm{KH}_{2} \mathrm{PO}_{4}, 1.3 \mathrm{mM} \mathrm{CaCl}_{2}$ and $5 \mathrm{mM}$ glucose ( $\mathrm{HH}$ buffer), and incubated for another $24-48 \mathrm{~h}$ in $\mathrm{HH}$ buffer at $37^{\circ} \mathrm{C}$ in a $95 \%$ air $/ 5 \% \mathrm{CO}_{2}$ atmosphere. At the indicated times, cells from a $6 \mathrm{~cm}$ culture dish were washed three times with ice-cold PBS, scraped into $250 \mu \mathrm{l}$ immunoprecipitation buffer (IPB.7 buffer), consisting of 
$20 \mathrm{mM}$ tri-ethanolamine, $0.7 \mathrm{M} \mathrm{NaCl}, 0.5 \%$ (v/v) NP-40, $4.6 \mathrm{mM}$ sodium deoxycholate, $1 \mathrm{mM} \mathrm{PMSF}, 0.01 \%$ (w/v) trypsin inhibitor (II-T), $\mathrm{pH}$ adjusted to 7.8 with $\mathrm{HCl}$. Directly after scraping, samples were frozen in liquid nitrogen and stored at $-80^{\circ} \mathrm{C}$.

SDS-PAGE was performed according to Laemmli (1970). After thawing, the samples were diluted in sample buffer to a protein concentration of $1 \mathrm{mg} / \mathrm{ml}$, heated for $10 \mathrm{~min}$ at $80^{\circ} \mathrm{C}$ and loaded onto $10 \%$ SDS polyacrylamide gels. After electrophoresis proteins were transferred to nitrocellulose membranes. After blocking with $5 \%(\mathrm{w} / \mathrm{v})$ fat-free dried milk, the membranes were incubated overnight with anti $\mathrm{Bcl}-2$ antibody $(1: 40)$. After washing, the filters were incubated with peroxidase-conjugated anti-mouse IgG $(1: 4000)$ for $2 \mathrm{~h}$ and immuno binding was detected by the enhanced chemiluminescence method according to the manufacturer.

\section{Exposure to cisplatin}

The monolayers of cells were washed three times with $\mathrm{HH}$ buffer. Cisplatin was dissolved in dimethylsulfoxide (DMSO) just prior to the experiment and diluted in $\mathrm{HH}$ buffer. Two $\mathrm{ml}$ of cisplatin solution was added per well and $10 \mathrm{ml}$ per $75 \mathrm{~cm}^{2}$ culture flask; the cells were incubated for the indicated times at $37^{\circ} \mathrm{C}$ in a $95 \%$ air $/ 5 \% \mathrm{CO}_{2}$ atmosphere. Final concentrations of DMSO never exceeded $0.1 \%$.

\section{Cell detachment assay}

Cells were cultured in six well dishes. The number of detached cells was determined by counting the cells using flow cytometry: after twice washing the monolayers in each well with $2 \mathrm{ml}$ ice-cold PBS, the cells from each washing were pooled, centrifuged ( $80 \mathrm{~g}$ for $6 \mathrm{~min}$ at $4^{\circ} \mathrm{C}$ ), resuspended in $200 \mu \mathrm{l}$ PBS, transferred to FACScan tubes and analyzed immediately, after addition of propidium iodide (PI) to a final concentration of $10 \mu \mathrm{M}$. Viability was determined by analyzing the PI fluorescence intensity with a FACScan flow cytometer. The number of detached cells was expressed as percentage of total cells present in the monolayer at $t=0$, i.e. the sum of the number of floating and attached cells. The latter were counted after harvesting the adherent cells by trypsinization.

\section{Fixation and fluorescent visualization of the cytoskeleton}

At the indicated times, the buffer, containing cisplatin, was removed from the monolayers on the coverslips in the six well dish and each well was washed three times with $2 \mathrm{ml}$ PBS pH 7.4. Cells were fixed for $20 \mathrm{~min}$ in $1.5 \mathrm{ml}$ PBS containing $4 \%$ (w/v) formaldehyde at room temperature. After washing three times with $2 \mathrm{ml} \mathrm{PBS}$, cells were incubated with $2 \mathrm{ml} 0.1 \%(\mathrm{w} / \mathrm{v}) \mathrm{NaBH}_{4}$ in PBS for $10 \mathrm{~min}$. Cells were washed three times with $2 \mathrm{ml} \mathrm{PBS}$ and incubated 10 min with $2 \mathrm{ml}$ $0.1 \%(\mathrm{w} / \mathrm{v})$ Triton-X-100 in PBS (PBS/triton) and subsequently with $2 \mathrm{ml} \mathrm{0.2 \%} \mathrm{(w/v)} \mathrm{BSA} \mathrm{in} \mathrm{PBS/triton} \mathrm{(PBS/Triton/BSA)} \mathrm{for} 10$ min prior to the staining.

F-actin was visualized using bodipy-phalloidin as follows: $80 \mu \mathrm{l}$ phalloidin solution (1:40 dilution of $200 \mathrm{U} / \mathrm{ml}$ stock in methanol) was put on parafilm; the coverslip was put on top of the drop with the cells facing the staining solution for $20 \mathrm{~min}$ at room temp, in a dark and humidified chamber.

After staining, the cells were put back in the six well dishes and washed three times with $2 \mathrm{ml}$ PBS/Triton/BSA and twice with $2 \mathrm{ml}$ PBS. Cells were mounted in a drop of PBS $50 \%$ glycerol $(w / v)$, containing $100 \mathrm{md} / \mathrm{ml}$ 1,4-diazobicyclo-octane (DABCO), sealed and stored at $-40^{\circ} \mathrm{C}$ until analysis.
Fluorescence images were made using a video intensified fluorescence microscope (VIFM) system, with a IM35 inverted microscope (Zeiss, Oberkochen, Germany), equipped with a Nikon $40 \mathrm{X} / 1.3$ NA CF Fluor objective. Images were recorded using a CCD instrumentation camera, controlled by a CC200 camera controller (Photometrics, Tucson, AZ, USA). Images were processed on an Imagine image processing system (Synoptics, Cambridge, UK) and stored on the hard disk of a Hewlett Packard 486 computer. Images were printed using a Mitshubishi colour video copy processor.

\section{Quantification of cell viability and percentage apoptotic cells by Acridine Orange/Ethidium Bromide uptake}

At the indicated times, the monolayers were washed twice with $\mathrm{HH}$ buffer, containing $2 \%(\mathrm{w} / \mathrm{v}) \mathrm{BSA}$, and the floating cells were pooled. Monolayers were stained with $2 \mathrm{ml}$ buffer containing $10 \mu \mathrm{M}$ acridine orange (AcOr) and $10 \mu \mathrm{M}$ ethidium bromide (EtBr) for $1 \mathrm{~min}$ at room temperature on the coverslip and analyzed immediately using VIFM. Pooled cells were stained in $1 \mathrm{ml}$ suspension with $10 \mu \mathrm{M}$ of both dyes, mixed gently by hand; $10 \mu \mathrm{l}$ of the cell suspension was put on a microscope slide, covered and analyzed immediately using VIFM. Cells were counted based on colour and appearance. Viable cells take up AcOr, giving them a green colour. Non-viable cells take up $\mathrm{EtBr}$, giving them an orange colour. Both dyes intercalate into DNA, allowing separation of four populations: (I) viable cells: green cells with intact nucleus; (II) early apoptotic cells: green cells with fragmented or condensed chromatin; (III) late apoptotic cells: orange cells with fragmented or condensed chromatin, and (IV) necrotic cells: orange cells with normal appearing chromatin structure (McGahon et al, 1995. Per coverslip 10 fields of 300 cells were counted. Each experiment was repeated three times. Results were confirmed by comparison of the percentage permeable (orange) cells obtained after (EtBr/AcOr) staining (counted by VIFM), with the percentage of PI positive cells analyzed by flow cytometry.

\section{Analysis of nuclear morphology in fixed cells using Hoechst 33258}

In some experiments, nuclear fragmentation was visualized in fixed cells. Fixation was performed as described above for staining of Factin. Apoptosis in fixed cells was determined by analyzing the morphology of the nucleus, after staining the cells with $80 \mu \mathrm{l}$ of $2 \mu \mathrm{g} / \mathrm{ml}$ Hoechst 33258 in PBS for 20 min at room temperature. If applicable, cells were stained for F-actin and the nucleus simultaneously, by using one drop with both $2 \mu \mathrm{g} / \mathrm{ml}$ Hoechst 33258 and $5 \mathrm{U} / \mathrm{ml}$ bodipyphalloidin. Cells were classified apoptotic, depending on the condensation and fragmentation of the chromatin. For each treatment 1000 cells were analyzed using VIFM.

\section{Northern and dot blot analysis}

The monolayers were rinsed three times with ice-cold PBS, and total RNA was isolated from the cells as described elsewhere (Chirgwin et al, 1977). Briefly, cells from one to three $75 \mathrm{~cm}^{2}$ culture flasks were pooled in 10-30 ml lytic solution and directly homogenized for $1 \mathrm{~min}$ on ice using an ultra-turrax T25 (Janke \& Kunkel, IKA Labortechnik, Heitersheim, Germany).

Northern and dot blot analysis were performed as previously described (Church and Gilbert, 1984). Aliquots of $20 \mu \mathrm{g}$ RNA were denatured in a solution containing $50 \%(\mathrm{w} / \mathrm{v})$ deionized formamide, 
2.2 $\mathrm{M}$ formaldehyde, and MOPS buffer $(20 \mathrm{mM}$ 3-(N morpholino)propanesulphonic acid, $1.0 \mathrm{mM}$ EDTA, $5.0 \mathrm{mM}$ sodium acetate, $\mathrm{pH} 7.0)$ for $15 \mathrm{~min}$ at $55^{\circ} \mathrm{C}$. Electrophoresis was performed in $1 \%(\mathrm{w} / \mathrm{v})$ agarose gels containing $2.2 \mathrm{M}$ formaldehyde. After electrophoresis, RNA was stained with ethidium bromide and transferred to Zetabind nylon membrane (CUNO laboratory, Meriden, CN, USA). The transferring buffer consisted of 20 times concentrated SSC buffer (SSC buffer: $0.15 \mathrm{M} \mathrm{NaCl}$ and $0.015 \mathrm{M}$ sodium citrate, $\mathrm{pH} 7.0$ ).

Dot blot analysis was performed according to Maniatis et al (1982). RNA was blotted on nylon membranes using a dot blot apparatus (BioRad, Cambridge, MA, USA); following transfer the filters were washed in $100 \mathrm{ml}$ PBS, dried and baked at $80^{\circ} \mathrm{C}$ for $4 \mathrm{~h}$.

Filters were prehybridized for $1 \mathrm{~h}$ in $0.5 \mathrm{M}$ sodium phosphate buffer, pH 7.0, containing 1 mM EDTA, 7\% SDS (w/v), 1\% (w/v) BSA and $50 \mu \mathrm{g} / \mathrm{ml}$ denatured salmon sperm DNA, and hybridized in the same buffer with ${ }^{32} \mathrm{P}$-labelled probe for $16-24 \mathrm{~h}$ at $65^{\circ} \mathrm{C}$. Following hybridization, the filters were washed once quickly with $100 \mathrm{ml}$ $2 \times$ SSC, containing $0.1 \%(\mathrm{w} / \mathrm{v})$ SDS, at room temperature and three times with $100 \mathrm{ml} 2 \times \mathrm{SSC}$, containing $0.1 \%(\mathrm{w} / \mathrm{v}) \mathrm{SDS}$, at $65^{\circ} \mathrm{C}$ for $20 \mathrm{~min}$. After hybridization with the cDNA probe for giyceraidehyde-3phosphate dehydrogenase (GAPDH), the last washing step was performed using $100 \mathrm{ml} 0.2 \times$ SSC, containing $0.1 \%(\mathrm{w} / \mathrm{v}) \mathrm{SDS}$. Filters were autoradiographed and the mRNA levels at the dot blots were quantitated using storage phosphor image technology (Molecular Dynamics, Sunnyvale, CA, USA).

The specific cDNA probes used were: pPE386 for the detection of mRNA encoding for laminin B chains (LN) (Barlow et al, 1984) a $720 \mathrm{bp} E c o \mathrm{Rl}-\mathrm{Pstl}$ fragment of rat fibronectin for detection of fibronectin (FN) mRNA (Schwarzbauer et al, 1983) and (pPE69) for detection of $\alpha 2$ collagen (IV) mRNA (COL) (Kurkinen et al, 1985). GAPDH was used as loading control for the blots. The probes were labelled with ${ }^{32} \mathrm{P}-\mathrm{dCTP}(3000 \mathrm{Ci} / \mathrm{mmol})$ (New England Nuclear, Dreieich, Germany) using a random primed labelling kit (Boehringer Mannheim, Mannheim, Germany) as described by the manufacturer. Unincorporated radionucleotides were removed by filtration through a column of Sephadex G50 and annealed by boiling for $5 \mathrm{~min}$. Specific radioactivity ranged between 0.5 and $2 \times 10^{9}$ c.p.m. $/ \mu \mathrm{g}$.

Specificity of the probes was checked on Northern blots. All probes labelled specifically RNA from both PPTC and LLC-PK1 cells located at the position corresponding to the locations obtained previously with RNA from mice (Munaut et al, 1992).

\section{Statistical analysis}

All values are expressed as mean \pm S.E.M. The statistical evaluation was performed with ANOVA. Results were considered significant if $P<0.05$.

\section{Acknowledgements}

This project was financially supported by the Dutch Foundation Platform Alternatives to Animal Experiments (MK) and by US public health grants DK 46267 and ES 07847 (JLS).

\section{References}

Andreucci VE (1984) Pathophysiology of ischemic/toxic acute renal failure, In: Acute Renal failure, Pathophysiology, Prevention and Treatment, edited by V.E. Andreucci eds (Boston, Martinus Niffloff Publishing), pp 1-50

Barlow DP, Green NM, Kurkinen M and Hogan BLM (1984) Sequencing of laminin B chains CDNAs reveals $\mathrm{c}$-terminal regions of coiled-coil alpha-helix. EMBO J. 3 : $2355-2362$
Brown SB, Bailey Kand Savill J (1997) Actin is cleaved during constitutive apoptosis. Biochem J. 323: 233-237

Chirgwin JM, Pryzbala AE, MacDonald RY and Rutter W (1977) Isolation of biologically active ribonucleic acid from sources enriched in ribonuclease. Biochemistry 18: 5294-5299

Church GM and Gilbert W (1984) Genomic sequencing. Proc. Nati. Acad. Sci. USA 81: $1991-1995$

Daugaard G (1990) Cisplatin nephrotoxicicty: experimental and clinical studies. Danish Medical Bulletin 37: 1-12

Fish RG, Shelley J, Badman MD, Mason M, Adams M and Paterson I (1994a) Platinum accumulation in adult cancer patients receiving cisplatin. Drug Invest. 7: $175-182$

Fish EM and Molitoris BA (1994b) Alterations in epithelial polarity and the pathogenesis of disease states. N Engl. J. Med. 330: 1580-1588

Frisch SM, Vuori K, Ruoslahti E and Chan Hui PY (1996) Control of adhesiondependent cell survival by focal adhesion kinase. J. Cell. Biol. 134: 793-799

Gallit J, Colflesh D, Rabiner I, Simone J and Goligorsky MS (1993) Redistribution and dysfunction of integrins in cultured renal epitheliai cell exposed to oxidative stress. Am. J. Physiol. 264: F149-F157

Haldar S, Basu A and Croce-CM (1997) Bcl2 is the guardian of microtubule integrity. Cancer Res. 57: 229-233

Henikoff S and Eghtedarzadeh MK (1987) Conserved arrangement of nested genes at the Drosophila Gart locus. Genetics. 117(4): 711-725

Hsu YT, Wolter KG and Youle RJ (1997). Cytosol-to-membrane redistribution of Bax and Bcl-X(L) during apoptosis. Proc. Natl. Acad. Sci. USA 94: 3668-3672

Kondo S, Yin D, Morimura T and Takeuchi J (1995) Combination therapy with cisplatin and nifedipine inducing apoptosis in multidrug-resistant human glioblastoma cells. J. Neurosurg. 82: 469-474

Kruidering M, Maasdarn DH, Prins FA, de Heer E, Mulder GJ and Nagelherhe JF (1994) evaluation of nephrotoxicity in vitro using a suspension of highly purified porcine proximal tubular cells and characterization of the cells in primary culture. Exp. Nephrol. 2: 334-344

Kruidering M, Van de Water B, De Heer E, Mulder GJ and Nagelherhe JF (1997) Cisplatin-induced nephrotoxicity in porcine proximal tubular cells: Mitochondrial dysfunction by inhibition of complexes I to IV of the respiratory chain. J. Pharmacol. Exp. Ther. 280(2): 638-649

Kroshian VM, Sheridan AM and Lieberthal W (1994) Functional and cytoskeleta changes induced by sublethal injury in proximal tubular epithelial cells. Am. J. Physiol. 266: F21-F30

Kurkinen M, Bernard MP, Barlow DP and Chow LT (1985) Characterization of 64-, 123 - and 182 base-pair exons in the mouse $\propto 2$ (IV) collagen gene. Nature 317 $177-179$

LaemmiiUK (1970) Cleavage of structural proteins during the assembly of the head of bacteriophage T4. Nature 227: 680-685

Lam M and Adelstein DJ (1986) Hypomagnesemia and renal magnesium wasting in ents treated with cisplatin. Am. J. Kidney diseases 8: 164-169

Lieberthal W, Triaca V and Levine J (1996) Mechanisms of death induced by cisplatin in proximal tubular epithelial cells: apoptosis vs necrosis. Am. J. Physiol. 270: F700-F708

Maniatis T, Fritsch EF and Sambrook J (1982) In: Molecular cloning, a laboratory manual USA; (Cold Spring Harbor lab), pp 7.54-7.55

McGahon AJ, Martin SJ, Bissonnette RP, Mahboubi A, Shi Y, Mogil RJ, Nishioka WK and Green DR (1995) The end of the cell line: Methods for the study of apoptosis in vitro. In: Schwartz LM and Osborne BA (eds), Methods in Cell Biology, (New York: Academic Press), vol. 46. (Cell Death), pp 153-185

Munaut C, Bergijk EC, Baelde JJ, Noël A, Foidart JM, and Bruijn JAA (1992) Molecular biologic study of extracellular matrix components during the development of glomeruloselerosis in murine chronic Graft-versus-Host disease. Lab. Invest. 67: 580-587

Prestayko AW, Crooke ST and Carter SK (eds) (1980) Cisplatin: current status and new developments. (New York, Acad Press).

Ruoslahti E (1996) Integrin signaling and matrix assembly. Tumour Bioi. 17: $117-$ 124

Schwarzbauer JE, Tamkun JW, Lemischka IR and Hynes RO (1983) Three different fibronectin mRNAs arise by alternative splicing within the coding region. Cell 35: $421-431$

Solez K (1991) Acute Renal Failure. In: Hepstinall R(eds) Pathology of the kidney. 4th edition. (Boston: Little, Brown and Co.), pp 1235-1314 
Van de Water B, Jaspers JJ, Maasdam DH, Mulder GJ and Nagelherhe JF (1994) In vivo and in vitro detachment of proximal tubular cells and F-actin damage: consequences for renal function. Am. J. Physiol. 267: F888-899

Van de Water B, Kruidering M and Nagelherhe JF (1996) F-actin disorganization in apoptotic cell death of cultured rat renal proximal tubular cells. Am. J. Physiol. 270: $\mathrm{F} 593-\mathrm{F} 603$

Vaux DL and Weissman IL (1993) Neither macromolecular synthesis nor myc is required for cell death via the mechanism that can be controlled by $\mathrm{Bcl}-2$. Mol. Cell. Biol. 13: 7000-7005
Zeng HH, Wang K, Wang B and Zhang Y (1996) Studies on the thermokinetic characterization of actin polymerization and the effect of cisplatin. Int. J. Biol. Macromol. 18: $161-166$

ZhangZ, Wori K, Reed JC and Ruoslahti E (1995) The alpha 5 beta 1 integrin supports survival of cells on fibronectin and up-regulates Bcl-2 expression. Proc. Natl. Acad. Sci. USA 92: 6161-6165 